\title{
Two Cheers for the Foreign Tax Credit, Even in the BEPS Era
}

\section{Citation}

J. Clifton Fleming, Jr., Robert J. Peroni \& Stephen E. Shay, Two Cheers for the Foreign Tax Credit, Even in the BEPS Era, 91 Tulane L. Rev. 1 (2016).

\section{Published Version}

http://www.tulanelawreview.org/91-fleming/

\section{Permanent link}

http://nrs.harvard.edu/urn-3:HUL.InstRepos:29399778

\section{Terms of Use}

This article was downloaded from Harvard University's DASH repository, and is made available under the terms and conditions applicable to Other Posted Material, as set forth at http:// nrs.harvard.edu/urn-3:HUL.InstRepos:dash.current.terms-of-use\#LAA

\section{Share Your Story}

The Harvard community has made this article openly available.

Please share how this access benefits you. Submit a story.

Accessibility 


\title{
TULANE LAW REVIEW
}

\begin{tabular}{lll}
\hline \hline VOL.91 & NOVEMBER 2016 & No. 1 \\
\hline \hline
\end{tabular}

\section{Two Cheers for the Foreign Tax Credit, Even in the BEPS Era*}

\author{
J. Clifton Fleming, Jr.,** Robert J. Peroni,,*** \\ and Stephen E. Shay ${ }^{* * * *}$
}

Reform of the U.S. international income taxation system has been a hotly debated topic for many years. The principal competing alternatives are a territorial or exemption system and a worldwide system. For reasons summarized in this Article, we favor worldwide taxation if it is real worldwide taxation; that is, a nondeferred U.S. tax is imposed on all foreign income of U.S. residents at the time the income is earned. However, this approach is not acceptable unless the resulting double taxation is alleviated. The longstanding U.S. approach for handling the international double taxation problem is a foreign tax credit limited to the U.S. levy on the taxpayer's foreign income. Indeed, the foreign tax credit is an essential element of the case for worldwide taxation. Moreover, territorial systems often apply worldwide taxation with a

* $\quad$ (C) 2016 by J. Clifton Fleming, Jr., Robert J. Peroni \& Stephen E. Shay. All rights reserved. Thanks for comments on earlier drafts of this Article from Omri Marian, Alvin C. Warren, Jr., participants in the Doctor of International Business Taxation Program at the Vienna University of Economics and Business, and participants in an international tax panel at the Southeastern Association of Law Schools 2015 annual meeting. The views expressed in this Article are those of the authors and do not reflect those of their universities, any organization for which any of the authors serves as an officer or renders pro bono services, or, in the case of Mr. Shay, any client.

** Ernest L. Wilkinson Chair and Professor of Law, J. Reuben Clark Law School, Brigham Young University.

*** Fondren Foundation Centennial Chair for Faculty Excellence and Professor of Law, The University of Texas School of Law. Professor Peroni dedicates this Article to his loving parents, Betty Peroni and the late Emil Peroni, for their tremendous support and inspiration over the years. Professor Peroni thanks Dean Ward Farnsworth and the University of Texas School of Law for their generous research support.

**** Senior Lecturer, Harvard Law School. Mr. Shay discloses certain activities not connected with his position at Harvard Law School, one or more of which may relate to the subject matter of this Article, at https://helios.law.harvard.edu/public/ConflictOfInterest Report.aspx?id=10794. 
foreign tax credit to all income of resident individuals as well as the passive income and tax haven income of resident corporations. Thus, the foreign tax credit also is an important feature of many territorial systems.

The foreign tax credit has been subjected to sharp criticisms though, and Professor Daniel Shaviro has recently proposed replacing the credit with a combination of a deduction for foreign taxes and a reduced U.S. tax rate on foreign income. In this Article, we respond to the criticisms and argue that the foreign tax credit is a robust and effective device. Furthermore, we respectfully explain why Professor Shaviro's proposal is not an adequate substitute. We also explore an overlooked aspect of the foreign tax credit-its role as an allocator of the international tax base between residence and source countries - and we explain the credit's effectiveness in carrying out this role. Nevertheless, we point out that the credit merits only two cheers because it goes beyond the requirements of the ability-to-pay principle that underlies use of an income base for imposing tax (instead of a consumption base). Ultimately, the credit is the preferred approach for mitigating international double taxation of income.

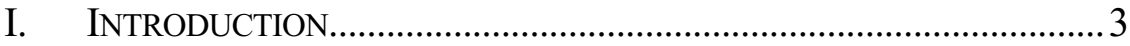

II. THE IMPORTANCE, OR NOT, OF CAPITAL EXPORT

NEUTRALITY

III. The Possible Contribution OF THE ForeIGN TAX

CREDIT TO MORE AGGRESSIVE SOURCE TAXATION

A. Why Not a Deduction Instead of a Credit?.

B. Expanded Source Taxation

1. Increased Source Tax Rates.........................................20

2. Aggressive Expansion of Source Tax Bases: The Effect of BEPS …..................................................22

IV. MINIMIZING FoREIGN TAXES .....................................................26

A. Introduction............................................................26

B. Stateless/Homeless Income.....................................27

C. Elective Benefits Under Foreign Income Tax

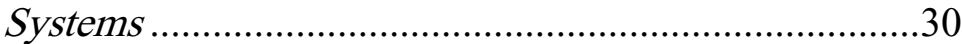

D. Choosing Between Foreign Countries .......................... 31

E. Replacing the Foreign Tax Credit with a Combination of a Deduction and a Preferential

Tax Rate: A Response to Professor Shaviro.

V. The Foreign TAX CREDIT AS Allocator of THE INTERNATIONAL INCOME TAX BASE: COMMENTS ON INTERNATION EQUITY

A. Territorial Compared with Worldwide .........................41

B. Searching for Allocation Principles ...............................43

C. The Plight of Developing Countries

VI. A PRINCIPLED, NONMANIPULABLE DEFINITION OF

RESIDENCE IS ESSENTIAL

VII. WHY ONLY TWO CHEERS?. 
VIII. CONCLUSION.

\section{INTRODUCTION}

Under customary international law, every country has a right to impose both source-based taxation on income earned within its borders by foreign persons ${ }^{1}$ and residence-based taxation on the worldwide incomes - that is, the sum of domestic and foreign income - of its own residents. ${ }^{2}$ If two countries fully exercise these indisputable rights in relation to the same income, international double taxation is inevitable. This is because residents of any given country who earn income in a second country will have that income taxed by the second country under its source taxation right and by the residence country under its residence taxation right. ${ }^{3}$ This double taxation would be a serious impediment to international commerce and result in a decline in economic efficiency and each country's economic welfare. ${ }^{4}$ Consequently, customary international law prescribes that the source taxation right is paramount and that

1. See Restatement (ThiRd) OF the Foreign Relations LaW of the United

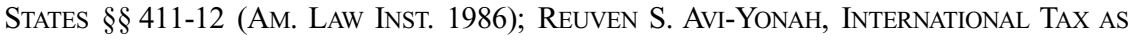
INTERNATIONAL LAW: AN ANALYSIS OF THE INTERNATIONAL TAX REgIME 27 (2007); Ilan Benshalom, The New Poor at Our Gates: Global Justice Implications for International Trade and Tax Law, 85 N.Y.U. L. Rev. 1, 75 (2010); Allison Christians, Sovereignty, Taxation and Social Contract, 18 MinN. J. INT'L L. 99, 104, 110-11 (2009); Manal S. Corwin, Sense and Sensibility: The Policy and Politics of BEPS, 145 TAX NOTES 133, 138 (2014); Jinyan Li, Improving Inter-nation Equity Through Territorial Taxation and Tax Sparing, in GlobalizATION AND Its TAX Discontents: TAX Policy AND INTERNATIONAL INVESTMENTS 117, 120 (Arthur J. Cockfield ed., 2010); Wolfgang Schön, International Tax Coordination for a Second-Best World (Part I), WorLd TAX J., Oct. 2009, at 67, 72-73. For normative justifications of this rule, see ROY ROHATGI, BASIC INTERNATIONAL TAXATION 12 (2002); Stephen E. Shay, J. Clifton Fleming, Jr. \& Robert J. Peroni, The David R. Tillinghast Lecture, "What's Source Got to Do with It?" Source Rules and U.S. International Taxation, 56 TAX L. REV. 81, 88-106 (2002).

2. See Restatement (ThiRd) OF the Foreign Relations LaW OF the United StATES § 412(1)(a) (AM. LAW InST. 1986); Avi-YonAH, supra note 1, at 22-27; Benshalom, supra note 1, at 75; Christians, supra note 1, at 104, 110-11; Corwin, supra note 1, at 138; Schön, supra note 1, at 90-91. For a normative justification of this rule, see RoHATGI, supra note 1, at 12; J. Clifton Fleming, Jr., Robert J. Peroni \& Stephen E. Shay, Fairness in International Taxation: The Ability-to-Pay Case for Taxing Worldwide Income, 5 FLA. TAX REv. 299 (2001) [hereinafter Fleming, Peroni \& Shay, Fairness in International Taxation]. For a discussion of the connection of source-based taxation and residence-based taxation to the international law concept of sovereignty, see Diane M. Ring, What's at Stake in the Sovereignty Debate?: International Tax and the Nation-State, 49 VA. J. INT'L L. 155 (2008).

3. See Charles H. Gustafson, Robert J. Peroni \& Richard Crawford Pugh, TAXATION OF InTERNATIONAL TRANSACTIONS 22, 304 (4th ed. 2011); IMF, Spillovers in International Corporate Taxation, Policy Paper, at 9 (May 2014); Schön, supra note 1, at 7273.

4. See Gustafson, Peroni \& PUgh, supra note 3, at 23-24, 304. 
residence countries ${ }^{5}$ have the unilateral responsibility to mitigate international double taxation by adjusting the residence tax burden. ${ }^{6}$

The exemption system is one of the two commonly used unilateral methods by which residence countries discharge this responsibility. ${ }^{7}$ Under this approach, foreign business income that bears a meaningful foreign tax is eliminated (exempted) from the residence country's income tax base so that it bears a zero residence tax. $^{8} \quad$ This approach is also commonly called a territorial system because a country that employs it taxes only income generated within its territorial borders.

The other principal approach for providing unilateral relief from international double taxation is a worldwide system with a foreign tax credit.' A country employing such a system imposes a tentative tax on

5. The residence country is the country where the taxpayer is a resident. Obviously, the definition of resident is critically important but is outside the scope of this Article. For discussions of this issue, see Hugh J. Ault \& Brian J. Arnold, Comparative Income Taxation: A Structural Analysis 431-36 (3d ed. 2010); Gustafson, Peroni \& Pugh, supra note 3, at 41-60; 1 JOEL D. KUNTZ \& ROBERT J. PERONI, U.S. INTERNATIONAL TAXATION ๆ B1.02[2] (1992 \& 2016 cum. sup. no. 2).

6. See Restatement (ThiRd) OF the Foreign Relations LaW of the United StATES $§ 413 \mathrm{cmt}$. a (AM. LAW INST. 1986); see also Org. for Econ. Co-operation and Dev. [OECD], Model Tax Convention on Income and on Capital, arts. 23A, 23B (July 15, 2014), http://www.oecd.org/tax/treaties/model-tax-convention-on-income-and-on-capital-2015-fullversion-9789264239081-en.htm [hereinafter OECD, Model Tax Convention] (prescribing methods countries may use to eliminate double taxation); U.N. Dep't of Econ. \& Soc. Aff., Model Double Taxation Convention Between Developed and Developing Countries, arts. 23A, 23B (2011), http://www.un.org/esa/ffd/documents/UN_Model_2011_Update.pdf; Yariv Brauner, An International Tax Regime in Crystallization, 56 TAX L. REV. 259, 265-66, 284 (2003).

7. See Cong. Budget Office, Pub. No. 4150, Options for Taxing U.S. MultinAtional CORPORATIONS 3 (2013) [hereinafter CBO, OptiONS FOR TAXING]; J. Clifton Fleming, Jr., Robert J. Peroni \& Stephen E. Shay, Formulary Apportionment in the U.S. International Income Tax System: Putting Lipstick on a Pig?, 36 Mich. J. INT’L L. 1, 16-18 (2014) [hereinafter Fleming, Peroni \& Shay, Formulary Apportionment].

8. See sources cited supra note 7. However, some countries, including Canada and the Netherlands, allow foreign business income to qualify for exemption without regard to whether it has been subjected to a "meaningful" level of foreign tax. See Staff of JoINT COMM. ON TAXATION, JCX-33-11, BACKGROUND AND SELECTED ISSUES RELATED TO THE U.S. INTERNATIONAL TAX SYSTEM AND SYSTEMS THAT EXEMPT FoREIGN BuSINESS INCOME 19-20, 32-33 (2011) [hereinafter JOINT COMM., BACKGROUND AND ISSUES].

9. A country can tax its residents on their worldwide incomes without a credit for foreign taxes and, instead, allow its residents to treat foreign tax payments as deductible expenses in calculating their residence country tax liability. This approach is largely ineffective in alleviating international double taxation and is little used. See STAFF OF JOINT COMM. ON TAXATION, JCX-22-06, THE IMPACT OF INTERNATIONAL TAX REFORM: BACKGROUND AND SELECTED ISSUES RELATING TO U.S. INTERNATIONAL TAX RULES AND THE COMPETITIVENESS OF U.S. BuSINESSES 60 (2006) [hereinafter JoINT CoMM., IMPACT OF International Tax Reform]; Gustafson, Peroni \& Pugh, supra note 3, at 23-24. Moreover, allowing only a deduction for foreign income taxes would conflict with the income 
the worldwide income of each resident and then mitigates double taxation by subtracting a credit for foreign source country tax from the tentative residence country tax. ${ }^{10}$ If the residence country tax is greater than the source country tax, the residence country collects only the excess, which is commonly referred to as a residual tax. ${ }^{11}$ If the foreign source country tax is equal to or greater than the tentative residence country tax, the residence country collects nothing. ${ }^{12}$ However, the U.S. foreign tax credit is limited to the amount of tentative residence country tax that would otherwise apply to the foreign-source taxable income. ${ }^{13}$ Thus, the United States does not reimburse taxpayers for source tax in excess of the tentative U.S. residence country tax on foreign-source taxable income from the same foreign tax credit limitation category. ${ }^{14}$

tax treaty obligations of the United States to allow a foreign tax credit in mitigation of double taxation. See United States Model Income Tax Convention, U.S. DEP'T TREASURY art. 23 (Feb. 17, 2016), https://www.treasury.gov/resource-center/tax-policy/treaties/Documents/ Treaty-US\%20Model-2016.pdf [hereinafter 2016 U.S. MODEL]. The United States previously allowed only $90 \%$ of foreign taxes as a credit against the alternative minimum tax. In Lindsey v. Commissioner, the Tax Court upheld the validity of the $90 \%$ limitation on the foreign tax credit against alternative minimum tax despite the U.S.-Switzerland income tax treaty, under which the United States agreed to allow a foreign tax credit to avoid double taxation. Lindsey v. Comm'r, 98 T.C. 672,677 (1992), aff'd, 15 F.3d 1160 (D.C. Cir. 1994). This $90 \%$ limit was enacted by the Tax Reform Act of 1986, Pub. L. No. 99-514, § 701(a), 100 Stat. 2085, 2320-45, but was repealed by the American Jobs Creation Act of 2004, Pub. L. No. 108-357, § 421(a)(1), 118 Stat. 1418, 1574.

10. See CBO, Options for TAXing, supra note 7, at 3; Gustafson, Peroni \& Pugh, supra note 3 , at 39, 307-08.

11. See Gustafson, Peroni \& Pugh, supra note 3, at 39, 307-08, 485-91. U.S. residual tax is the U.S. income tax liability that remains after a credit for foreign income tax is subtracted from the U.S. income tax that would be imposed if no credit were allowed.

12. See Ault \& ARNOLD, supra note 5, at 447.

13. See Gustafson, Peroni \& Pugh, supra note 3, at 39, 406-08. Foreign-source taxable income for this purpose is determined by foreign tax credit limitation category and after taking into account deductions allocable to the foreign-source income, including an allocable share of deductions incurred by a shareholder claiming an indirect credit under I.R.C. § 902. See 1 KUnTZ \& PERONI, supra note 5, ๆף A2.05[2], B4.16[2][a]. We have previously observed that U.S. rules likely under-allocate such indirect expenses to foreignsource income. See J. Clifton Fleming, Jr., Robert J. Peroni \& Stephen E. Shay, Designing a U.S. Exemption System for Foreign Income When the Treasury is Empty, 13 FLA. TAx Rev. 397, 448-50 (2012); Stephen E. Shay, J. Clifton Fleming, Jr. \& Robert J. Peroni, Territoriality in Search of Principles and Revenue: Camp and Enzi, 141 TAX NOTES 173, 181 (2013); see also Report of the Task Force on International Tax Reform, 59 TAx LAW. 649, $765-71$ (2006) (providing an overview of how expenses are allocated and apportioned under U.S. law). As a consequence, the limitation is expanded, which may result in an over-allowance of foreign taxes as a credit. The rules for allocating deductions to foreign-source income are a critical element in properly determining income under a foreign tax credit limitation or a territorial system of taxation but will not be discussed in detail here.

14. JOINT COMM., IMPACT OF INTERNATIONAL TAX REFORM, supra note 9, at 65-66; Report of the Task Force on International Tax Reform, supra note 13. This is a standard 
In prior work we have explained that although the United States purports to operate a worldwide system with a foreign tax credit, deferral, ${ }^{15}$ loose transfer pricing enforcement, and cross-crediting ${ }^{16}$ actually cause the U.S. regime to function largely as an overly complex and elective territorial system. ${ }^{17}$ Our work has pointed out that to transform the present U.S. system into a real worldwide system, it is necessary to abolish or severely limit deferral and to structure the foreign tax credit so that cross-crediting is substantially curtailed. ${ }^{18}$

Obviously, the foreign tax credit is a critically important element with respect to both (1) the current U.S. international income tax regime and (2) a U.S. regime that is reformed into a real worldwide system. The credit is, however, also important in the systems of countries that employ exemption or territorial regimes. This is so because those systems are typically applied only to active foreign business income of resident corporations that is subject to a meaningful level of foreign tax. ${ }^{19}$ Countries using these regimes often apply worldwide taxation to all passive foreign income and tax haven foreign business income received by their corporate residents and to both active and passive foreign income earned by their noncorporate

international practice. See Paul R. McDaniel, Territorial vs Worldwide International Tax Systems: Which Is Better for the U.S.?, 8 FLA. TAX REV. 283, 298 (2007). Under current law, as a result of changes made by Congress in 2004 legislation, the U.S. foreign tax credit limitation generally has only two categories: (1) foreign-source passive income and (2) all other foreign-source income. I.R.C. § 904(d) (2012). Under certain circumstances, income may be isolated into a separate foreign tax credit limitation category. See, e.g., id. $\S 865(\mathrm{~h})(1)(\mathrm{B})$.

15. The deferral privilege is a feature of U.S. international income tax law that generally allows a U.S. person to conduct profitable overseas business or investment activities through a low-taxed controlled foreign corporation without paying U.S. residual tax until the controlled foreign corporation distributes its foreign-source earnings or until the U.S. person sells the foreign corporation's stock. See GuSTAFSOn, Peroni \& PUGH, supra note 3, at 24-26.

16. Cross-crediting occurs when foreign tax credits in excess of U.S. tax on hightaxed foreign-source income are used to reduce the U.S. residual tax on low- or zero-taxed foreign-source income. See CBO, OptIONS FOR TAXING, supra note 7, at 7-9; GuSTAFSON, PERONI \& Pugh, supra note 3, at 407-10; 1 Kuntz \& PERONI, supra note 5, ๆ B4.16[5][a]; J. Clifton Fleming, Jr., Robert J. Peroni \& Stephen E. Shay, Worse than Exemption, 59 EMORY L. J. 79, 132-37 (2009) [hereinafter Fleming, Peroni \& Shay, Worse than Exemption].

17. See generally Fleming, Peroni, \& Shay, Worse than Exemption, supra note 16 (explaining why the current U.S. system functions much like an elective and poorly designed territorial regime); Edward D. Kleinbard, Stateless Income, 11 FLA. TAX REV. 699, 717-26 (2011) [hereinafter Kleinbard, Stateless Income].

18. See Fleming, Peroni \& Shay, Formulary Apportionment, supra note 7, at 18-20. If deferral were abolished, aggressive transfer pricing would have much reduced importance with regard to outbound international business activity.

19. See JoINT COMM., BACKGROUND AND ISSUES, supra note 8 , at 8 . 
residents. ${ }^{20}$ Whenever this income is also taxed in the country where it is earned, double taxation results. Accordingly, exemption system countries often make a foreign tax credit available with respect to these types of income. ${ }^{21}$

Thus, the soundness of the foreign tax credit as a double tax mitigation device is an important matter for both worldwide and territorial regimes. The credit has been criticized for being somewhat more complex than the exemption or territorial approach. ${ }^{22}$ This criticism is indisputable, ${ }^{23}$ and although we have previously suggested certain simplifications, ${ }^{24}$ substantial complexity is an unavoidable characteristic of a well-functioning foreign tax credit regime. We have explained that this complexity should nevertheless be tolerated because it falls mostly on a relatively small population of taxpayers who have the sophistication and resources to address it. ${ }^{25}$ In addition,

20. See JoInt COMM., BACKGROUND AND Issues, supra note 8, at 8; STAFF OF JoINT COMM. ON TAXATION, JCS-02-05, OPTIONS TO IMPROVE TAX COMPLIANCE AND REFORM TAX EXPENDITURES 187, 190 (2005) [hereinafter JOINT COMM., OPTIONS TO IMPROVE]; Approaches To Improve the Competitiveness of the U.S. Business Tax System for the 21st Century, U.S. DEP'T TREASURY 57, 59-60 (Dec. 20, 2007), https://www.treasury.gov/resourcecenter/tax-policy/Documents/Report-Improve-Competitiveness-2007.pdf; AULT \& ARNOLD, supra note 5, at 447-48; Kleinbard, Stateless Income, supra note 17, at 717; Katrin Laschewski \& Christian Laschewski, The Impact of the International Tax System of the Home Country on the Location Decision of a Foreign Permanent Establishment: The Case of Germany, 7 WORLD TAX J. 171, 172-74 (2015).

21. See JoInt COMm., BACKground And Issues, supra note 8; Ault \& ARnOLD, supra note 5, at 448-51; see also STAFF OF JOINT COMM. ON TAXATION, JCX-55-08, ECONOMIC EFFiciency and Structural ANALYSES of Alternative U.S. TAX POLICIES FOR Foreign Direct Investment 24 (2008) [hereinafter Joint Comm., Alternative Policies] (explaining that a U.S. exemption system would employ a foreign tax credit with respect to non-exempt income); Kleinbard, Stateless Income, supra note 17, at 717.

22. See JoInt COMM., Options To IMProve, supra note 20, at 189, 193-94; President's Advisory Panel on Fed. Tax Reform, Simple, Fair, and Pro-Growth: Proposals to Fix AmericA's Tax System, U.S. DeP't Treasury 104, 134 (Nov. 2005), https://www.treasury.gov/resource-center/tax-policy/Documents/Report-Fix-Tax-System-2005. pdf; AulT \& ARNOLD, supra note 5, at 448; 2 NAT'L ForEIGN TRADE COUNCIL, THE NFTC Foreign InCOMe Project: InTERnAtional TAX Policy fOR the 21st CENTURY 52 (2001) [hereinafter NFTC 2]. For a classic commentary on the complexity of the U.S. foreign tax credit and the causes thereof, see Charles I. Kingson, The Foreign Tax Credit and Its Critics, 9 AM. J. TAX POL'Y 1, 3-15 (1991).

23. But see J. Clifton Fleming, Jr. \& Robert J. Peroni, Exploring the Contours of a Proposed U.S. Exemption (Territorial) Tax System, 109 TAX NoTES 1557, 1560-68 (2005) (explaining that well-designed territorial systems are significantly complex); Kingson, supra note 22, at 52-54 (same).

24. See Robert J. Peroni, A Hitchhiker's Guide to Reform of the Foreign Tax Credit Limitation, 56 SMU L. REV. 391 (2003) (explaining ways in which the foreign tax credit can be simplified); Robert J. Peroni, J. Clifton Fleming, Jr. \& Stephen E. Shay, Reform and Simplification of the U.S. Foreign Tax Credit Rules, 101 TAX NoTEs 103 (2003) (same).

25. See Fleming, Peroni \& Shay, Formulary Apportionment, supra note 7, at 28; see also JOEL SlEMrOD \& CHRISTIAN GILLITZER, TAX SySTEMS 8-9 (2014) ("[C]omplexity in the 
a foreign tax credit that restricts cross-crediting contributes significantly to making income taxation a nonfactor in deciding whether to locate new or expanded business activity in the United States or in a low-tax foreign country. ${ }^{26}$ Moreover, the foreign tax credit allows the United States to collect a residual tax on the foreignsource income of U.S. residents when the foreign tax is less than the U.S. tax. Not only does this benefit the U.S. fisc, it also affirms the principle of ability-to-pay, which requires that the foreign-source income of U.S. residents be included in the U.S. income tax base. ${ }^{27}$ In contrast, the exemption or territorial approach provides an incentive to locate business activities in low-tax countries, even in cases where a business activity conducted there has a lower pretax return than an equivalent U.S. business activity. ${ }^{28}$ In contrast, territoriality loses residual tax revenue, stimulates the shifting of profits to low-tax countries, ${ }^{29}$ and conflicts with the ability-to-pay principle by excluding the foreign income of U.S. residents from the tax base. ${ }^{30}$

Nevertheless, the foreign tax credit has also been criticized because (1) its prohibition against reimbursement for foreign taxes in

tax/transfer system can be a powerful policy tool to discriminate between deserving and undeserving transfer program recipients."); Kingson, supra note 22, at 14 ("[The 1986 Tax Reform Act's] foreign tax credit amendments can therefore be viewed as only foisting the same sort of complexity on people more equipped to cope with it.").

26. See Jane G. Gravelle, Cong. Research SerV., RL34115, Reform of U.S. InTERnATIONAL TAXATION: AlteRnatives 5-7, 10-11 (2015); J. Clifton Fleming, Jr., Robert J. Peroni \& Stephen E. Shay, Perspectives on the Worldwide vs. Territorial Taxation Debate, 125 TAX Notes 1079, 1084-85 (2009) [hereinafter Fleming, Peroni \& Shay, Perspectives].

27. See Blueprints for Basic Tax Reform, U.S. DeP'T TrEASURY 98-99 (Jan. 17, 1977), https://www.treasury.gov/resource-center/tax-policy/Documents/Report-Blueprints1977.pdf; Benshalom, supra note 1, at 74-75.

28. See CBO, OPTIONS FOR TAXING, supra note 7, at 22-23; GRAVELLE, supra note 26, at 5-6; Mark P. Keightley \& Jeffrey M. Stupak, Cong. Research Serv., R44013, Corporate Tax Base Erosion and Profit Shifting (BEPS): An Examination of the Data 16 (2015); Fleming, Peroni \& Shay, Perspectives, supra note 26, at 1084-85.

29. See KeIGHTLEy \& STUPAK, supra note 28, at 17; see also Kimberly A. Clausing, The Effect of Profit Shifting on the Corporate Tax Base, 150 TAx NOTES 427 (2016) ("[T]he revenue cost to the U.S. government from profit shifting . . was likely between $\$ 77$ billion and $\$ 111$ billion per year by $2012 . ”)$.

30. See Hugh J. Ault \& David F. Bradford, Taxing International Income: An Analysis of the U.S. System and Its Economic Premises, in TAXATION IN THE GLOBAL ECONOMY 11, 27 (Assaf Razin \& Joel Slemrod eds., 1990) ("[S]ince the source of income has no bearing on its validity as a measure of ability to pay, the tax burden should be based on "worldwide income."'). For an explanation of how this principle applies to corporate income, see Fleming, Peroni \& Shay, Fairness in International Taxation, supra note 2, at 318-27. See also Joel Slemrod, Why'd You Have To Go and Make Things So Complicated?, in TAX SimplificAtion 1, 7 (Chris Evans, Richard Krever \& Peter Mellor eds., 2015) ("Any change in the tax law in the apparent direction of simplification will also have some equity and efficiency implications."). 
excess of U.S. tax on foreign-source income means that it does not strictly conform to the economic standard of capital export neutrality; ${ }^{31}$ (2) it might encourage low-tax foreign countries to plunder U.S. residual tax revenue by raising their rates of tax on U.S. residents up to the U.S. rate, ${ }^{32}$ and (3) it does not provide U.S taxpayers with an incentive to minimize their foreign tax liabilities so that U.S. residual tax on their foreign income is maximized. ${ }^{33}$ Part II of this Article deals with the relationship between the foreign tax credit in a real worldwide system and capital export neutrality. Part III addresses the point that the foreign tax credit might motivate lowtax foreign countries to appropriate U.S. residual tax revenue by increasing their tax on income earned within their borders by U.S. residents. Part IV discusses the possibility that the foreign tax credit might make U.S. residents apathetic towards reducing their foreign tax liabilities so long as those liabilities are not greater than the limitation on the credit. In Part V, we recognize that the foreign tax credit has an important effect in addition to mitigating international double taxation - it is a critical element in allocating the international income tax base between residence countries and source countries. We then evaluate the foreign tax credit as a tax base allocator in comparison to an exemption for foreign-source income. In Part VI, we acknowledge the necessity of a robust definition of corporate residence and preview our forthcoming work on that topic. Part VII explains why the foreign tax credit merits only two cheers in spite of its comparative virtues that make it superior to all other approaches for mitigating double taxation. The conclusion summarizes our analysis and findings.

31. See Gravelle, supra note 26, at 10-11; JoInt Comm., IMPACT OF InTERNATIONAL TAX REFORM, supra note 9, at 3; AULT \& ARNOLD, supra note 5 at 454-55; 1 NAT'L FOREIGN Trade COUnCIL, The NFTC Foreign InCOME PROJECT: InTERnATIONAL TAX PoliCy FOR THE 21st CENTURY 5-6, 8 (2001) [hereinafter NFTC 1]; Ault \& Bradford, supra note 30, at 40.

Capital export neutrality is an economic standard holding that taxation should be a neutral factor in a taxpayer's choice between carrying on economic activity in the taxpayer's residence country or in a foreign country. It is given effect in its purest form when the taxpayer's residence country taxes each resident's worldwide income as it is earned and provides the resident with an unlimited credit for foreign income taxes imposed on that income. See Gravelle, supra note 26, at 5-6, 10-11; Gustafson, Peroni \& Pugh, supra note 3 , at 20 .

32. See Stanley S. Surrey, Current Issues in the Taxation of Corporate Foreign Investment, 56 COLUM. L. REV. 815, 823 (1956). Surrey did not, however, endorse this criticism.

33. See DANiel N. ShaViro, Fixing U.S. International TAXation 24 (2014); Alan D. Viard, PPL: Exposing the Flaws of the Foreign Tax Credit, 139 TAX NOTES 553, 561-62 (2013); see also Martin A. Sullivan, Shaviro's Fixing U.S. International Taxation, 143 TAX NOTES 641 (2014) (providing a complimentary review of Professor Shaviro's position). 


\section{THE IMPORTANCE, OR Not, OF CAPITAL EXPORT NEUTRALITY}

Some critics of real worldwide taxation assert that it is based entirely on the economic standard of capital export neutrality. ${ }^{34}$ This has led some to imply that the foreign tax credit, which is a crucial element of worldwide taxation, is incoherent because it is not fully consistent with capital export neutrality. ${ }^{35}$ In this Part, we explain why this criticism is mostly incorrect and, more importantly, unilluminating.

The economic standard of capital export neutrality holds that a business or investment activity should bear the same income tax burden regardless of whether the activity takes place in the taxpayer's residence country or in a foreign country. ${ }^{36}$ The standard's underlying rationale is that its application makes income taxation a neutral factor in deciding where to locate business or investment activity so that the decision is based on a comparison of economic merits, thereby contributing to greater worldwide efficiency and economic growth than would be the case if tax considerations drove the choice of location. $^{37}$ Example 1 explores these points.

Example 1: USCo is a Delaware corporation whose shares are entirely owned by U.S. residents. Its U.S. effective tax rate is $35 \%$. USCo is considering expanding its business. The location options are the United States or either of two foreign countries - Lowtaxia and Hightaxia. If the expansion occurs in the United States, the before-tax return will be $10 \%$, and the effective tax rate will be $35 \%$. If, on the other hand, the expansion occurs through a Lowtaxia branch, ${ }^{38}$ the before-tax rate of

34. See Gary Clyde Hufbauer, U.S. TAXation of International Income: BLUEPRINT FOR REFORM 51-52 (1992); NFTC 2, supra note 22, at 5-6; Mihir A. Desai, C. Fritz Foley \& James R. Hines Jr., Domestic Effects of the Foreign Activities of US Multinationals, 1 AM. ECON. J.: ECON. POL'Y 181, 201 (2009).

35. See NFTC 1, supra note 31, at 5-6; Ault \& Bradford, supra note 30, at 40.

36. See Gravelle, supra note 26, at 5-6, 10-11; JOINT COMM., IMPACT OF International TAX Reform, supra note 9, at 57; Gustafson, Peroni, \& Pugh, supra note 3, at 20. This means that foreign-source income should be subject to nondeferred U.S. taxation to the same extent as U.S.-source income. See Kingson, supra note 22, at 16.

37. See Gravelle, supra note 26, at 5-6, 10-11; JoInT COMM., IMPACT of InTERNATIONAL TAX REFORM, supra note 9, at 57-58; Michael J. GRAETZ, Follow THE MONEY: ESSAYS ON INTERNATIONAL TAXATION 94, 295 (2016) [hereinafter GRAETZ, FOLLOW THE Money]; Gustafson, Peroni \& Pugh, supra note 3, at 20; Michael J. Graetz, The David R. Tillinghast Lecture, Taxing International Income: Inadequate Principles, Outdated Concepts, and Unsatisfactory Policies, 54 TAX L. REv. 261, 270 (2001) [hereinafter Graetz, Inadequate Principles].

38. The assumption that USCo would use a branch structure simplifies the example by eliminating deferral of U.S. income tax on USCo's foreign-source income. Example 1 could be revised to include deferral, along with additional facts, so that the ultimate outcome would be unchanged. However, nothing would be gained from the increased complexity. 
return will be $9 \%$, but the effective tax rate will be only $5 \%$. However, expansion through a Hightaxia branch will produce a $12 \%$ before-tax return, and the effective tax rate will be $50 \%$.

Purely from the standpoint of worldwide efficiency, the most desirable outcome is for USCo to ignore the 50\% tax in Hightaxia and do its expansion there because the before-tax rate of return would be $12 \%$ (as compared to $10 \%$ in the United States). ${ }^{39}$ Worldwide efficiency also requires USCo to forgo the attractive Lowtaxia 5\% tax because the before-tax rate of return there is only $9 \%$. These are the behaviors that capital export neutrality seeks to induce. ${ }^{40}$

The U.S. system of current taxation of foreign branch income coupled with a foreign tax credit would attain the correct capital export neutrality result with respect to the Lowtaxia option because there would be a 5\% Lowtaxia levy plus a 30\% U.S. residual tax after the United States allowed a foreign tax credit for the Lowtaxia levy. This sum would equal the $35 \%$ U.S. tax that would apply if the expansion occurred in the United States. ${ }^{41}$ Thus, the U.S./Lowtaxia rate differential would be neutralized. The after-tax return of a Lowtaxia expansion would be $5.85 \%$, ${ }^{42}$ while the after-tax return for a U.S. expansion would be $6.5 \%{ }^{43}$ This after-tax comparison would cause USCo's management to choose U.S. expansion with its $10 \%$ before-tax return instead of Lowtaxia expansion which yields only $9 \%$ before tax. This result is consistent with capital export neutrality. ${ }^{44}$

However, as noted above, ${ }^{45}$ the preferred capital export neutrality result would be for USCo to do the expansion in Hightaxia rather than either Lowtaxia or the United States. This is so because a Hightaxia expansion would yield a $12 \%$ before-tax return, which is greater than the return in either Lowtaxia or the United States. ${ }^{46}$ This result would be achieved if the United States reimbursed USCo for the 15 percentage points of tax by which the Hightaxia levy exceeds the U.S. tax. The effective tax rate on the Hightaxia expansion income would then be $35 \%,{ }^{47}$ resulting in an after-tax return of $7.8 \%,{ }^{48}$ which is

39. Pretax return is the standard metric for determining locational efficiency. See JOINT COMM., IMPACT OF INTERNATIONAL TAX REFORM, supra note 9, at 57-58.

40. See sources cited supra note 31 .

41. $5 \%+(35 \%-5 \%)=35 \%$.

42. $9 \% \times(1-.35)=5.85 \%$.

43. $10 \% \times(1-.35)=6.5 \%$.

44. See sources cited supra note 31; Fleming, Peroni \& Shay, Perspectives, supra note 26 , at $1084-85$.

45. See supra text accompanying notes $39-40$.

46. See sources cited supra note 31 .

47. $50 \%-15 \%=35 \%$. 
obviously higher than the after-tax return in either Lowtaxia (5.85\%) or the United States (6.5\%). Faced with these comparisons USCo's management would execute the expansion in Hightaxia, and capital export neutrality would be upheld.

This will not happen though. Neither the United States nor, apparently, any other country that uses the foreign tax credit will explicitly reimburse its residents for foreign tax incurred in excess of domestic tax. ${ }^{49}$ Specifically, in Example 1's Hightaxia scenario, the U.S. foreign tax credit claimed against U.S. tax would be limited to the $35 \%$ U.S. tax so that the effective tax rate on the Hightaxia expansion income would be $50 \%$ (zero U.S. tax, after a credit for 35 percentage points of Hightaxia tax, plus the 50\% Hightaxia levy). This would leave the Hightaxia expansion with a $6 \%$ after-tax return ${ }^{50}$ compared with a $6.5 \%$ after-tax return in the United States. Accordingly, USCo would forgo the Hightaxia 12\% before-tax return in favor of the U.S. 10\% before-tax return. The efficiency goal of capital export neutrality would be thwarted, and the limited foreign tax credit would be the culprit.

For several reasons, however, this is not a tragedy. First, it is doubtful that the worldwide efficiency goal of capital export neutrality would be meaningfully furthered if the United States

48. $12 \% \times(1-.35)=7.8 \%$.

49. As stated by Professor Paul McDaniel:

A completely implemented CEN [capital export neutrality] policy would require that the U.S. refund all foreign taxes in excess of the U.S. tax on foreign source income. Such a rule, of course, would put U.S. revenues completely at the mercy of foreign countries' tax rates. Neither the U.S. nor any other FTC [foreign tax credit] country will accept or has accepted this result.

McDaniel, supra note 14, at 298.

In the real world, of course, USCo might execute half of the expansion in Lowtaxia and half in Hightaxia. Under current U.S. law, the 15 percentage points of excess Hightaxia tax could be deducted from ("cross-credited" against) the 30 percentage points of the U.S. residual tax on the Lowtaxia income. See Fleming, Peroni \& Shay, Worse than Exemption, supra note 16, at 132-37. This would achieve the same result as a U.S. reimbursement of USCo's excess Hightaxia tax and would make the Hightaxia expansion attractive after tax. To avoid the need to construct a more complex version of Example 1, we have omitted the crosscrediting scenario and given USCo an either/or choice between Lowtaxia and Hightaxia. This does not affect the points made in the analysis. Under-allocation of expenses also can result in crediting an amount in excess of an effective 35\% rate. See supra note 13 . Our discussion assumes appropriate expense allocation rules.

50. $12 \% \times(1-.50)=6 \%$. Professor David Elkins has argued that after-tax returns rather than pretax returns should be used for such comparisons. See David C. Elkins, The Merits of Tax Competition in a Globalized Economy, 91 IND. L. J. 905, 928 (2016). This appears to be a minority view. See JoInt COMM., IMPACT OF InTERnATIONAL TAX REForm, supra note 9, at 57-58. We disagree with it because pretax returns are the better measure of total economic production. 
unilaterally removed the limitation from its foreign tax credit, thus reimbursing USCo in Example 1 for the 15 percentage points of excess Hightaxia tax as well as reimbursing all other U.S. residents for excess tax incurred as a result of doing business or investing in hightax countries. This is because most developed countries have adopted territorial systems which exempt foreign-source business income from domestic taxation so that for their residents, only foreign tax is relevant with respect to their foreign-source income. ${ }^{51}$ Residents of these countries would, therefore, have a strong incentive to misallocate their capital by rejecting opportunities in countries like Hightaxia and, instead, pursuing inferior rates of return in low-tax countries where the low tax rate produces an attractive after-tax return. $^{52}$ In theory, this incentive might attract so much capital from exemption countries to low-tax countries that pretax rates of return in the latter will be driven down to a level that yields after-tax returns equivalent to after-tax returns in high-tax countries. ${ }^{53}$ But this equilibrium would be achieved only through what is, in terms of the rationale of capital export neutrality, a misallocation of capital. Because this misallocation is a consequence of the territorial systems that exist in most of the developed world, it is probably too large to be significantly corrected by the United States unilaterally changing to an unlimited foreign tax credit. ${ }^{54}$

Second, Americans rightly have elected their members of Congress to pursue policies that improve the well-being of Americans. When U.S. welfare is enhanced by tax policies that increase worldwide economic welfare, as economists generally believe to be the case with respect to tax policies that are consistent with free trade, ${ }^{55}$ then worldwide economic welfare is a laudable goal for U.S. policymakers. But the welfare of the American people must be the principal objective of U.S. tax policy. ${ }^{56}$

51. See, e.g., CBO, OptIONS FOR TAXING, supra note 7, at 5.

52. See Fleming, Peroni \& Shay, Perspectives, supra note 26, at 1084-85.

53. See Edward D. Kleinbard, The Lessons of Stateless Income, 65 TAX L. REV. 99, 106-07, 106 n.27 (2011) [hereinafter Kleinbard, Lessons].

54. See generally SHAVIRO, supra note 33, at 127-29 (arguing that U.S. investors have a limited capacity to shift global capital allocation).

55. See, e.g., id. at 116; Paul R. McDaniel, Trade and Taxation, 26 BRook. J. INT'L L. $1621,1625-26(2001)$.

56. See Graetz, Follow the Money, supra note 37, at 103; Shaviro, supra note 33, at 108-09; Graetz, Inadequate Principles, supra note 37, at 279; Viard, supra note 33, at 564. The analysis of U.S. welfare should be multifaceted and not be restricted solely to which country receives the revenue. The public expenditure of another country may advance U.S. welfare in numerous ways, including by providing security that also benefits the United 
In this light, it is important to recall that under international law, the United States has an obligation to eliminate double taxation resulting from its taxation of the foreign income of U.S. residents, but the obligation does not extend beyond that. Thus, in Example 1, if USCo, which is assumed to have a $35 \%$ U.S. effective tax rate, were to execute its business expansion in Hightaxia and suffer a $50 \%$ source country tax on its profits, the United States would fully satisfy its international law duty by crediting 35 percentage points of the Hightaxia levy against the U.S. tax on the Hightaxia profits. This would totally offset the U.S. tax, thereby eliminating double taxation because only the Hightaxia levy would be in place. Clearly, if the United States goes beyond a credit for 35 percentage points of the Hightaxia levy and reimburses USCo for the 15 percentage points of excess Hightaxia tax, the United States is paying a subsidy to support USCo's expansion in Hightaxia. ${ }^{57}$ Thus, when thinking about whether the United States should fully support the capital export neutrality principle by adopting an unlimited foreign tax credit, U.S. policymakers should be primarily focused on the issue of whether paying subsidies to U.S. multinationals to expand into low-tax foreign countries furthers the well-being of the American people. When the issue is framed in these terms, we are not aware of any empirical data that would provide economic support for paying these subsidies. ${ }^{58}$

States or by providing public goods that forestall excessive immigration of that country's residents to the United States.

57. See JoInt COMM., IMPACt OF InTERnational TAX REForm, supra note 9, at 6566; Robert J. Peroni, Back to the Future: A Path to Progressive Reform of the U.S. International Income Tax Rules, 51 U. MiAMI L. Rev. 975, 978 (1997); see also DANIEL N. SHAVIRO, DECODING THE U.S. CoRPORATE TAX 117 (2009) (explaining how foreign tax credits can be viewed as an "aggressive trade subsidy for U.S. companies"); Daniel J. Frisch, The Economics of International Tax Policy: Some Old and New Approaches, 47 TAX NotES 581, 583 (1990); Kingson, supra note 22, at 56.

58. Is the limited U.S. foreign credit also a subsidy in the form of a tax expenditure? We believe that the answer is no. Deciding whether to apply the tax expenditure label is not an end in itself. The object is to identify tax features that distort taxpayer behavior and then to subject those features to a broadly defined cost-benefit analysis. See generally J. Clifton Fleming, Jr. \& Robert J. Peroni, Reinvigorating Tax Expenditure Analysis and Its International Dimension, 27 VA. TAX REV. 437 (2008) [hereinafter Fleming \& Peroni, Reinvigorating Tax Expenditure Analysis] (explaining the underlying rationale of tax expenditure analysis). The purpose of the foreign tax credit is not to distort behavior. Instead, its purpose is to prevent distortion by ensuring that foreign-source income bears a total U.S. and foreign tax that is no less than the U.S. tax that would apply to a similar amount of domestic income. Some would argue that because of the U.S. foreign tax credit limitation, there is a distortion if the foreign tax exceeds the U.S. tax and that, in such a case, the foreign tax credit functions as a tax penalty or negative tax expenditure. In our view, however, the distortion or penalty results from the high tax in the foreign system, not the U.S. foreign tax credit limitation. Seeing no U.S.-caused distortion, we do not view a limited foreign tax 
An additional reason to be dubious about replacing the limited U.S. foreign tax credit with an unlimited credit is that it might expose the U.S. Treasury to raids by other countries. As the Organisation for Economic Co-Operation and Development (OECD) has observed:

$[\mathrm{P}]$ roviding an unlimited tax credit for foreign income and withholding tax would create incentives for capital importing countries to increase their host country tax burden, as this would increase host country revenues without affecting the combined host/home country tax burden on inbound FDI [foreign direct investment]. Thus foreign tax credit limitations are in order to avoid pure transfers of tax revenue from home to host countries .... ${ }^{59}$

Accordingly, a U.S. foreign tax credit that is limited to the U.S. tax on foreign-source income represents a prudential approach that appropriately protects the fisc. ${ }^{60}$ The issue of whether less developed foreign countries should be allowed to appropriate some or all of the U.S. tax base will be discussed further in Part V.

As shown with respect to Lowtaxia in Example 1, capital export neutrality produces correct results with respect to the decision by a U.S. resident to invest, or not, in a low-tax foreign country because it inhibits U.S. residents from pursuing opportunities that have lower pretax rates of return than those available at home. However, the preceding analysis indicates that capital export neutrality, which calls for an unlimited foreign tax credit, is not a useful policy guide with respect to a U.S. resident's decision on whether or not to invest in high-tax foreign countries. In that setting, capital export neutrality is

credit as either a tax expenditure or a negative tax expenditure or tax penalty. For a contrary view, see Patrick Driessen, Would Territoriality Be a Tax Expenditure?, 146 TAX NOTES 647, 651 (2015). But even if the limited foreign tax credit is a tax expenditure, it passes a costbenefit analysis for the reasons given in this Article.

59. Org. for Econ. Co-operation \& Dev. [OECD], Tax Effects on Foreign Direct Investment: Recent Evidence and Policy Analysis, at 99, Tax Policy Studies No. 17 (2007), http://www.oecd.org/ctp/tax-policy/39866155.pdf; see also JOINT COMM., IMPACT OF INTERNATIONAL TAX REFORM, supra note 9, at 65-66 (stating that a credit limitation is an important protective safeguard).

60. See Jane G. Gravelle \& Donald J. Marples, Cong. Research Serv., RL34494, The Foreign TAX CRedit's Interest Allocation Rules 5 (2008) (“[T]he purpose of the foreign tax credit limit is not to ensure the efficient allocation of resources; rather, it is concerned with protecting the U.S. tax base."); JOINT COMM., IMPACT OF INTERNATIONAL TAX REFORM, supra note 9, at 13 ("The foreign tax credit . . limit is intended to ensure that the credit serves its purpose of mitigating double taxation of foreign-source income without offsetting the U.S. tax on U.S.-source income.”). 
an incomplete principle. Thus, there is little reason to criticize the U.S. foreign tax credit for deviating from it. ${ }^{61}$

\section{The Possible Contribution of the Foreign TAX CRedit to MORE AgGressive SOURCE TAXATION}

\section{A. Why Not a Deduction Instead of a Credit?}

As just indicated in Part II, the United States has an understandable motivation for refusing to give a credit for foreign income tax payments in excess of the U.S. tax on the relevant income. To do otherwise would allow high-tax foreign countries to tax U.S. residents at rates in excess of the applicable U.S. rate without suffering any adverse consequences because the U.S. residents would be reimbursed by the credit for the excess tax. ${ }^{62}$ Thus, the excess foreign tax would effectively be paid with U.S. Treasury funds.

A moment's thought tells us that the same point can be made with respect to foreign income tax that does not exceed the U.S. limitation and is, therefore, fully creditable. The credit causes a

61. See Joint Comm., Impact of International TAx Reform, supra note 9, at 65 ('The only 'fault' of the foreign tax credit limitation in the context of capital export neutrality is that subsidies are not provided in the form of foreign tax credits in excess of domestic tax liability."). In earlier work, we have advocated real worldwide or full inclusion U.S. taxation - a regime that applies the U.S. income tax to foreign-source income as it is earned but that allows a credit, without significant cross-crediting, for any foreign tax on that income up to the level of the U.S. tax. See, e.g., Fleming, Peroni \& Shay, Formulary Apportionment, supra note 7, at 18-30; Fleming, Peroni \& Shay, Perspectives, supra note 26, at 1082-87, 1091-1106. Some critics characterize such a system as "commonly justified by appeal to the principle of capital export neutrality." Desai, Foley \& Hines, supra note 34, at 201. Although we conclude that of the various economic theories for structuring the taxation of international income, capital export neutrality, in its purest form, comes closest to prescribing the correct result, we also conclude that it is not completely satisfactory, particularly because it supports an unlimited foreign tax credit. See also IMF, supra note 3, at 72-73 (stating that capital export neutrality and other neutrality standards "provide only limited guidance . . . and indeed are rarely invoked in policy discussions"). Instead, our strong preference for real worldwide taxation is primarily driven by a desire to avoid the tax subsidies and distorted business and investment behavior that result from other approaches to international income taxation. Neutrality analysis can be helpful in identifying such subsidies and distortions. See Fadi Shaheen, On Fixing U.S. International Taxation, 9 Jerusalem Rev. Legal Stud. 125, 128 (2014) ("But neutrality norms remain invaluable tools for understanding and assessing the behavioral responses to and distortionary effects of taxation at the different margins. With these tools, we understand better today how different tax systems may affect saving, investment locations, and ownership patterns."); David A. Weisbach, The Use of Neutralities in International Tax Policy, 68 NAT'L TAX J. 635, 648 (2015) (“'A] decision to tax capital income means that we knowingly are distorting investment choices so the question is how best to do that, given the relevant goals and administrative concerns.").

62. See JoInt COMM., IMPACt OF InTERnAtional TAX REFORM, supra note 9, at 6566. 
dollar-for-dollar surrender of U.S. tax revenue, which reimburses the U.S. resident and effectively satisfies the foreign tax liability. If the United States does not accept that result to the extent of foreign tax payments in excess of the applicable U.S. domestic tax, why does it acquiesce with respect to foreign tax payments that come within this limit? Why does the United States not treat foreign income tax payments as non-creditable but deductible business expenses? Doing so would give recognition to the often recited mantra by U.S. multinationals that taxes are a business cost like any other, ${ }^{63}$ and the revenue loss to the Treasury would be greatly reduced, at least before dynamic effects are taken into account. A superficial answer to this question is that the bilateral income tax treaties between the United States and its major trading partners require the United States to give a credit rather than a deduction for income taxes paid to its treaty partners. $^{64}$

But more needs to be said. There is broad agreement that free trade benefits the United States and that obstacles to free trade should be mitigated. ${ }^{65}$ Allowing only a deduction for U.S. residents' foreign tax payments would discourage international trade because, according

63. See Amy S. Elliott, Tech Companies Defend International Tax Structures, 140 TAX NOTES 1530 (2013) ("Tax is a cost, like anything else, that we'd like to minimize so we can have more earnings to invest in the business.") (statement of the tax director of Adobe Systems, Inc.) (internal quotation marks omitted); see also SHAVIRO, supra note 33, at 9 ("[W]hen U.S. people pay foreign taxes, it truly is just an expense from our standpoint, no less than when they pay foreign fuel bills or labor costs, given that we don't get the money.").

64. See 2016 U.S. ModEL, supra note 9, art. 23. Another response is that a tax is just a business cost only in the eyes of the business taxpayer. Unlike that taxpayer's other expenses, taxes are used to pay for public goods that generally would not be supplied, or would not be supplied at a socially acceptable price and amount, by the private sector. In that sense, taxes are not just another expense but involve a broader social responsibility than the economic relationship with vendors supplying goods and services.

65. See Keightley \& Stupak, supra note 28, at 16; The Pros and Cons of Pursuing Free-Trade Agreements, CONG. BudGeT OfFiCE 2-3 (July 31, 2003), www.cbo.gov/sites/ default/files/108th-congress-2003-2004/reports/07-31tradebrief.pdf; HARRY G. BRAINARD, InTERNATIONAl ECONOMics AND PuBlic POLICY 5-6, 129, 193 (1954); McDaniel, supra note 55, at 1625-26; Joel B. Slemrod, Free Trade Taxation and Protectionist Taxation, 2 InT'L TAX \& PuB. FIn. 471, 472 (1995); see also The Effects of Liberalizing World Agricultural Trade: A Survey, Cong. Budget OfFICE viii, 11-12 (Dec. 2005), www.cbo.gov/sites/default/files/ 109th-congress-2005-2006/reports/12-01-tradelib.pdf (finding studies almost unanimously conclude that the United States would benefit from agricultural free trade); The Effects of NAFTA on U.S.-Mexican Trade and GDP, CONG. BUDGET OfFICE ix, xiv, 21-22 (May 2003), https://www.cbo.gov/sites/default/files/108th-congress-2003-2004/reports/report_0.pdf (finding that because Canada, Mexico, and the United States had previously made substantial progress in eliminating trade barriers among themselves, the North American Free Trade Agreement had only a small effect on U.S. GDP and that effect was positive). We recognize that not everyone benefits from free trade and strong measures are needed to mitigate harms to individuals adversely affected by trade. 
to familiar tax math, the U.S. tax would be reduced only by an amount equal to each taxpayer's U.S. marginal rate multiplied by the foreign tax. $^{66}$ The result would be partial double taxation that would be a barrier to international trade. ${ }^{67}$ Example 2 illustrates this point.

Example 2: Assume that USCo's marginal U.S. tax rate is $35 \%$ and that it could earn $\$ 100$ in Country $X$ and pay a $\$ 20$ Country X tax thereon or earn the same amount in the United States. If the $\$ 20$ were credited against the $\$ 35$ U.S. tax, the U.S. tax would be reduced by $\$ 20$ to $\$ 15$, and the U.S. and Country X taxes would add up to \$35 so that USCo would have the same $\$ 65$ after-tax result from earning the $\$ 100$ in either Country X or the United States. Taxes would be a neutral factor in USCo's decision to earn income at home or abroad. If, however, only a deduction were allowed for the $\$ 20$ Country $\mathrm{X}$ tax, the reduction in U.S. tax would be merely $\$ 7 .^{68}$ This would leave a U.S. tax of $\$ 28$. $^{69}$ The U.S. and Country X taxes would then add up to $\$ 48,{ }^{70}$ and USCo's after-tax income would be only $\$ 52^{71}$ instead of the $\$ 65$ after-tax income from U.S. activity. USCo would be deterred from expanding into Country X.

Moreover, if the United States terminated or renegotiated all of its treaties so that it was free to treat foreign income taxes as deductible rather than creditable costs, it is surely the case that its trading partners would seek changes that commensurately benefit their fiscs, and international trade would be adversely affected. For these reasons, it is sensible for the United States to accept the revenue loss resulting from allowing a credit for foreign income taxes that do not exceed U.S. tax on the relevant income.

The preceding discussion has focused entirely on active business income and the impact of taxation on deciding whether to locate business activity in the residence country or in a low-tax foreign country. The argument has been made that this type of analysis is generally inapposite with respect to passive income and that the proper approach is for residence countries generally to allow only a

66. See Joseph M. Dodge, J. Clifton Fleming, Jr. \& Robert J. Peroni, Federal INCOME TAX: DOCTRINE, STRUCTURE, AND POLICY 91-92 (4th ed. 2012).

67. See JoInt COMM., IMPACt OF INTERNATIONAL TAX REFORM, supra note 9, at 5960.

68. $\$ 20 \times 35 \%=\$ 7$.

69. $\$ 35-\$ 7=\$ 28$.

70. $\$ 28$ U.S. tax $+\$ 20$ Country $\mathrm{X}$ tax $=\$ 48$.

71. $\$ 100-\$ 48=\$ 52$. 
deduction for foreign income taxes imposed on their residents' foreign passive income. $^{72}$

In this Article, we are primarily concerned with the relationship of the foreign tax credit to the distinction between worldwide taxation versus territorial taxation. Speaking broadly, territorial systems eliminate this distinction with respect to passive income by imposing worldwide taxation with a foreign tax credit on such income. ${ }^{73}$ Consequently, this Article will focus on the foreign tax credit in the context of active business income. In that context, worldwide taxation with a foreign tax credit is the preferred approach if the worldwide system eliminates deferral and cross-crediting.

\section{B. Expanded Source Taxation}

This, however, does not end the debate. It has been suggested that U.S. willingness to accept the revenue cost of the foreign tax credit might cause other countries to increase their taxation of U.S. residents up to the credit limitation. ${ }^{74}$ The rationale for their doing so would be that the credit would effectively place the enlarged foreign tax burden on the U.S. Treasury so that the increased foreign tax would not impact U.S. residents and would not deter them from doing business or investing in the taxing countries. The principal ways in which foreign countries could implement this strategy would be to raise their source tax rates up to the U.S. foreign tax credit limitation ${ }^{75}$ or to indirectly achieve the same result by aggressively expanding their respective source tax bases.

72. See Graetz, Follow The Money, supra note 37, at 305-11; Deborah A. Geier, Some Thoughts on the Incidence of Foreign Taxes, 87 TAX NOTES 541, 551 (2000); Michael J. Graetz \& Itai Grinberg, Taxing International Portfolio Income, 56 TAX L. REV. 537, 568-74 (2003).

73. See JOINT COMM., BACKGROUND AND ISSUES, supra note 8 , at 8 .

74. See Surrey, supra note 32, at 823; see also Allison Christians, What the Baucus Plan Reveals About Tax Competition, 72 TAX NOTES INT'L 1113, 1115 (2013) (stating that if the United States adopted real worldwide taxation, the U.S. tax rate on income earned by U.S.-owned foreign subsidiaries would increase and the tax rate imposed by other countries could increase to match the residual U.S. rate because other countries would rely on the foreign tax credit to "stabilize the new status quo"); Ajay Gupta, U.S. Creditability and Foreign Environmental Levies, 80 TAX NoTES INT'L 134 (2015) ("The United States ... offers a foreign tax credit .... As a result, foreign jurisdictions heavily dependent on inflows of U.S. capital no longer have to worry about bidding up after-tax returns on foreign investment by lowering their own tax rates.").

75. See Li, supra note 1, at 127 ("[I]f the residence country adopts a credit system and limits the credit to the amount of domestic tax otherwise payable, it implicitly allows the source country to tax income at the 'soak-up' rate - that is, a rate equal to that in the residence country."). 


\section{Increased Source Tax Rates}

There are several reasons why the scenario of increased source tax rates is unlikely. First, the use of low source tax rates as a competitive strategy to attract foreign investment from many countries in addition to the United States has become widespread, even in developed economies. ${ }^{76}$ This competition would restrain a foreign country from increasing its rates solely to exploit the U.S. foreign tax credit. Thus, raising source tax rates to take advantage of the U.S. foreign tax credit would not be a likely strategy, at least in a country where U.S. investment was not dominant, unless the increases were confined to income earned by U.S. residents and their controlled foreign corporations.

Such a discriminatory rate strategy would, however, collide with the fact that the bilateral income tax treaties between the United States and its major trading partners generally prohibit the treaty partners from taxing the business income of U.S. residents more burdensomely than the partners tax their own residents. ${ }^{77}$ Accordingly, a low-tax treaty partner could not raise its tax rate on U.S. residents in order to exploit the U.S. foreign tax credit unless it also applied the same tax burden to its own residents. The likelihood of political opposition is obvious.

In addition, the regulations provide that a foreign tax is creditable for purposes of the U.S. foreign tax credit "only to the extent that liability for the foreign tax is not dependent (by its terms or otherwise) on the availability of a credit for the foreign tax against

76. See generally StafF of Joint COMM. ON TAXATION, JCX-51-15, PreSENT LAW and SElected Policy IsSues in the U.S. TAXATION OF Cross-Border InCOME 38-47 (2015) [hereinafter JOINT COMM., TAXATION OF CROSS-BORDER INCOME] (providing an assessment of the competitiveness of the U.S. tax system within the larger global economy); Org. for Econ. Co-operation and Dev. [OECD], Harmful Tax Competition: An Emerging Global Issue (1998), http://www.oecd.org/tax/transparency/44430243.pdf; Mindy Herzfeld, The U.K. Embraces Tax Competition and BEPS, 75 TAX NOTES INT'L 85 (2014).

77. For example, the 2016 U.S. Model Income Tax Treaty provides:

Enterprises of a Contracting State, the capital of which is wholly or partly owned or controlled, directly or indirectly, by one or more residents of the other Contracting State, shall not be subjected in the first-mentioned Contracting State to any taxation or any requirement connected therewith that is more burdensome than the taxation and connected requirements to which other similar enterprises of the first-mentioned Contracting State are or may be subjected. 
income tax liability to another country." ${ }^{\text {"78 }}$ The regulations give the following example:

Country $\mathrm{X}$ imposes a tax on the receipt of royalties from sources in country X by nonresidents of country X. The tax is 15 percent of the gross amount of such royalties unless the recipient is a resident of the United States or of country A, B, C, or D, in which case the tax is 20 percent of the gross amount of such royalties. Like the United States, each of countries A, B, C, and D allows its residents a credit against the income tax otherwise payable to it for income taxes paid to other countries. Because the 20 percent rate applies only to residents of countries which allow a credit for taxes paid to other countries and the 15 percent rate applies to residents of countries which do not allow such a credit, one-fourth of the country $\mathrm{X}$ tax would not be imposed on residents of the United States but for the availability of such a credit. Accordingly, one-fourth of the country $\mathrm{X}$ tax imposed on residents of the United States who receive royalties from sources in country $X$ is dependent on the availability of a credit for the country $\mathrm{X}$ tax against income tax liability to another country. ${ }^{79}$

Thus, a low-tax country could not raise its corporate income tax rate on U.S. residents so as to take full advantage of the U.S. foreign tax credit limitation unless it was willing to apply the same rate to residents of other countries. Most of these other countries employ territorial systems that provide an exemption for active foreign business income, rather than a foreign tax credit. Consequently, if a low-tax source country increased its source tax across the board, the impact on residents of territorial countries would be fully borne by those residents without any incremental assistance from a foreign tax credit that reflected the increased source country tax. The obvious negative effect on the ability of the source country to attract equity capital investment from the large number of territorial countries should, in the present environment of tax competition, discourage source countries from going down this road.

This issue, however, has a converse - the possibility that so long as a foreign country's tax burden does not exceed the amount of the available U.S. foreign tax credit, U.S. residents will not undertake the costs of the tax planning necessary to lawfully minimize the foreign

78. Treas. Reg. § 1.901-2(c)(1) (2006); see also Treas. Reg. § 1.903-1(b)(2) (applying the soak-up tax rule to "in lieu of" taxes under I.R.C. $\S 903)$. Foreign taxes for which liability is dependent on the availability of a foreign tax credit are often called "soak-up taxes" and these regulations disallow any foreign tax credit to the extent that a foreign tax is a soak-up tax. See Gustafson, Peroni \& PUgh, supra note 3, at 331-33.

79. Treas. Reg. $\S 1.901-2(\mathrm{c})(2)$, ex. 1. 
tax, with the result that the United States will lose residual tax revenue. We will discuss that topic in Part IV.

\section{Aggressive Expansion of Source Tax Bases: The Effect of BEPS}

In principle, a foreign country that does not wish to raise its source tax rate can leave its rate unchanged but enlarge its source tax base sufficiently to produce the same revenue increase as a higher tax rate. In recent years, some countries have employed this tactic by intensifying the enforcement of their transfer pricing rules. ${ }^{80}$ Even more recently, the OECD's BEPS initiative ${ }^{81}$ has suggested that countries should strengthen their source tax regimes by expanding the permanent establishment concept, increasing the effectiveness of transfer pricing rules, and limiting deductions for payments of interest, royalties, and services fees to foreign related parties (earnings stripping payments). ${ }^{82}$ Indeed, the United Kingdom has now acted unilaterally to enhance its source tax base by effectively enlarging its

80. See, e.g., Archana Sarda Mody, Emerging Trends in Indian Transfer Pricing, 71 TAX NOTES INT'L 633 (2013).

81. At the request of the G-20 nations, the OECD undertook a project to address the damage to national tax bases made by base erosion and profit shifting, commonly referred to by the acronym of BEPS. The object of the BEPS project was to generate a set of tax-baseprotection proposals. See Yariv Brauner, What the BEPS?, 16 FLA. TAX REV. 55, 58 (2014); Sol Picciotto, Can the OECD Mend the International Tax System?, 71 TAx NOTES INT'L 1105,1105 (2013). For data regarding the size of the profit shifting concern that was targeted by the BEPS project, see KEIGHTLEY \& STUPAK, supra note 28, at 10-13 (stating that IMF data shows that the ten largest national economies in the world have an average inbound foreign direct investment position equal to $25 \%$ of GDP while the ten countries that are most popular foreign direct investment destinations have an average inbound foreign direct investment position equal to $961 \%$ of GDP); Francis Weyzig, Still Broken: Governments Must Do More To Fix the International Corporate Tax System, Oxfam InT'L 5 (Nov. 2015), https://www.oxfam.org/sites/www.oxfam.org/files/file_attachments/bn-still-broken-corporatetax-101115-embargo-en.pdf ("[I]n 2012, US multinationals shifted between $\$ 500$ and $\$ 700 \mathrm{bn}$ in profits from countries where their real economic activities took place to countries where lower effective tax rates apply.").

82. See Org. for Econ. Co-operation and Dev. [OECD], OECD/G20 Base Erosion and Profit Shifting Project Explanatory Statement, at 7-8, 14-16 (2015), https://www.oecd. org/ctp/beps-explanatory-statement-2015.pdf [hereinafter OECD, Explanatory Statement]; Org. for Econ. Co-operation and Dev. [OECD], Action Plan on Base Erosion and Profit Shifting, at 16-17, 19-20 (2013), https://www.oecd.org/ctp/BEPSActionPlan.pdf [hereinafter OECD, Action Plan]; see also T. Timothy Tuerff, David Ware, Ronald D. Dickel \& Michael P. Reilly, Practical Implementation of the OECD's Base Erosion and Profit Sharing (BEPS) Action Plan, TAXES - TAX MAG., June 2015, at 107, 110 ("We're already ... having countries, mainly in Asia, assert PE status solely based on our marketing activities. So, we're already seeing it. I mean, they're not waiting for this to be concluded at the OECD project level."). For our recent suggestions regarding the earnings stripping problem, see J. Clifton Fleming, Jr., Robert J. Peroni \& Stephen E. Shay, Getting Serious About Cross-Border Earnings Stripping: Establishing an Analytical Framework, 93 N.C. L. REV. 673 (2015). 
concept of permanent establishment, ${ }^{83}$ and Australia has taken similar action. $^{84}$

To the extent that foreign countries collect more creditable source tax from U.S. residents, the United States must, subject to its foreign tax credit limitation, grant larger foreign tax credits and collect less residual tax. Thus, it is no surprise that the United States has expressed concerns about the source tax expansion aspects of the BEPS project. ${ }^{85}$

While these matters obviously concern the United States, it is unlikely that they are caused to any extent by the existence of the U.S. foreign tax credit. Instead, the developments mentioned above are driven by the desires of other countries to protect their source tax bases from erosion through aggressive transfer pricing and through inbound sales arrangements that exploit the limitations of the permanent establishment concept. ${ }^{86}$ To the extent that U.S. law has had any effect, the effect principally has come from the U.S. disregarded entity rules, ${ }^{87}$ which enhance the capacity of U.S. multinationals to erode foreign source tax bases by moving income from high-tax foreign countries to low-tax foreign intermediary jurisdictions. $^{88}$ In this context, the U.S. foreign tax credit is not a significant factor in actions by foreign countries.

83. Effective April 1, 2015, the United Kingdom adopted a "diverted profits tax." In general, this new regime imposes a $25 \%$ tax on profits that would have been earned through a U.K. permanent establishment if its existence had not been avoided by successfully exploiting limitations in the definition of permanent establishment. See Karen Hughes, H. Todd Miller, Rupert Shiers \& Christine Lane, The U.K. Diverted Profits Tax, J. TAX'N, July 2015, at 37, 39; Sol Picciotto, The U.K.'s Diverted Profits Tax: An Admission of Defeat or a Pre-Emptive Strike?, 77 TAx Notes InT'L 239 (2015); Marie Sapirie, Diverted Profits Tax Undermines BEPS Consensus, 146 TAX Notes 301 (2015); Philip Wagman, The U.K. Diverted Profits Tax: Selected U.S. Tax Considerations, 147 TAX NotES 1413 (2015).

84. See Ryan Finley, Diverted Profits Tax Proposal Would Strengthen ATO's Position, 82 Tax Notes InT'L 535 (2016); Mindy Herzfeld, Different Ways To Deem a PE, 79 TAX Notes InT'L 289 (2015); Ben Lannan, Australian Budget Measures Align with BEPS Project, 79 Tax Notes InT'L 761 (2015); Kristen A. Parillo, Australia Antiavoidance Bill Targets Multinationals, 79 TAX NOTES INT'L 912 (2015).

85. See Ryan Finley, Stack Gives U.S. Perspective on BEPS Recommendations, 149 TAX Notes 354 (2015); Robert B. Stack, Stack Discusses the Progress and Future of BEPS, 147 TAX Notes 1593 (2015). For a heated critique of the U.S. response to BEPS, see Ajay Gupta, The U.S. and BEPS - Return of the Big Bad Bully, 79 TAX NOTES INT'L 563, 563-64 (2015).

86. See OECD, Explanatory Statement, supra note 82, at 7-8; OECD, Action Plan, supra note 82 , at $15-17,19-21$.

87. See Treas. Reg. § 301.7701-2(c)(2) (2006).

88. See Kleinbard, Stateless Income, supra note 17, at 727-37; Bret Wells \& Cym Lowell, Tax Base Erosion and Homeless Income: Collection at Source Is the Linchpin, 65 TAX L. Rev. 535 (2012); see also Stephen E. Shay, J. Clifton Fleming, Jr. \& Robert J. Peroni, 
Of course, as noted above, some have expressed concerns that actions by foreign countries to collect more source tax from U.S. residents will result in the United States allowing larger foreign tax credits and suffering lower tax collections from its residents, even if the U.S. foreign tax credit is not an animating cause behind the foreign behavior. ${ }^{89}$ The implicit argument seems to be that foreign income accumulated offshore in controlled foreign corporations will eventually be repatriated to the United States, at which time the United States will collect a tax that will be greatly diminished if increased foreign source taxes generate large U.S. foreign tax credits. In the context of the present U.S. system, there are several reasons why this concern is exaggerated.

First, a significant amount of this foreign income has likely been returned to the United States ${ }^{90}$ in the form of investments that are freed from repatriation tax by loopholes in $\S 956$ of the Subpart F regime. $^{91}$ To this extent, the potential residual tax with respect to unrepatriated earnings is unlikely to be materially affected by

Designing a 21st Century Corporate Tax-An Advance U.S. Minimum Tax on Foreign Income and Other Measures to Protect the Base, 17 Fla. Tax Rev. 669, 690-92 (2015) [hereinafter Shay, Fleming \& Peroni, Designing a 21st Century Corporate Tax].

89. See Hearing on the OECD Base Erosion and Profit Shifting Project Before the Subcomm. on Tax Pol'y of the H. Comm. on Ways \& Means, 114th Cong. 10 (2015) (statement of Barbara M. Angus) ("[T] U.S. worldwide tax system means that the cost of increased foreign taxes on U.S.-based companies will be borne in part by the U.S. fisc through reduced residual U.S. tax when foreign earnings are repatriated."); National Foreign Trade Council Before the Subcomm. on Tax Pol'y of the H. Comm. on Ways \& Means, 114th Cong. (2015) (statement of Catherine Schultz, Vice President for Tax Pol'y, Nat'l Foreign Trade Council) (“As other governments increase taxes on U.S. multinational companies, the U.S. will provide Foreign Tax Credits to those companies to offset double taxation on the same income. As the number of Foreign Tax Credits increases, we will see more base erosion — but this time, it will be the U.S. base that is being eroded.").

90. See Stephen E. Shay, The Truthiness of 'Lockout': A Review of What We Know, 146 TAX NoTES 1393, 1395 (2015).

91. See I.R.C. § 956(c)(2)(A),(F) (2012) (permitting nontaxable repatriations made in the form of deposits in U.S. banks, purchases of debt obligations of the U.S. government and of unrelated domestic corporations, and purchases of stock of unrelated domestic corporations). See generally GUSTAFSON, PERONI \& PUGH, supra note 3, at 587-89 (defining U.S. property and discussing exclusions to the definition of U.S. property for taxation purposes and requirements for banks and corporations to treat investments in property as excluded from taxation under $\S 956$ ); 1 KUNTZ \& PERONI, supra note 5, \ B3.06[2] (same). In other words, many of the untaxed offshore profits are not really being held offshore. See David Kocieniewski, Why Microsoft, with $\$ 100$ Billion, Wants a Loan for LinkedIn, BLOOMBERG (June 13, 2016), www.bloomberg.com/news/articles/2016-06-13/whymicrosoft-with-100-billion-is-borrowing-to-buy-linkedin ("In Microsoft's most recent quarterly report, the company reported $\$ 102.8$ billion in untaxed profits controlled by its offshore subsidiaries, 81 percent of which was held in U.S. government securities.”). 
additional foreign taxes and related U.S. credits resulting from law changes prompted by the BEPS recommendations.

Second, much of the foreign income that remains offshore in controlled foreign corporations has been designated as indefinitely reinvested for financial accounting purposes so that taxable repatriation is not likely to occur in the reasonably foreseeable future. ${ }^{92}$ Moreover, when taxable repatriation does occur, the U.S. residual tax may be mitigated by planning to take advantage of the liberal crosscrediting of foreign taxes on other income permitted by the present version of the U.S. foreign tax credit limitation. ${ }^{93}$ Therefore, the revenue that would be jeopardized by larger foreign tax credits is comparatively small. For these reasons, there seems to be little cause for concern that expanded foreign source tax bases will result in a meaningful revenue loss to the United States under its present international income tax system.

If the United States were, however, to adopt a real worldwide income tax regime that reached the foreign-source income of U.S. residents as it was earned, ${ }^{94}$ significant amounts of revenue would be exposed to reduction by foreign tax credits resulting from expanded foreign source tax regimes. ${ }^{95}$ Nevertheless, so long as the foreign measures are permitted by the U.S. bilateral treaty network, ${ }^{96}$ or by international $\mathrm{law}^{97}$ in the case of countries outside that network, the

92. See Lee A. Sheppard, Debunking the Overseas Cash Meme, 147 TAX NotES 847 (2015).

93. See Fleming, Peroni \& Shay, Worse than Exemption, supra note 16, at 132-37. The foreign tax credit limitation was substantially weakened in the American Jobs Creation Act of 2004, Pub. L. No. 108-357, § 404, 118 Stat. 1418, 1494-97. For a critique and discussion of this weakening, see GUSTAFSON, PERONI \& PUGH, supra note 3, at 419-23.

94. See Robert J. Peroni, J. Clifton Fleming, Jr. \& Stephen E. Shay, Getting Serious About Curtailing Deferral of U.S. Tax on Foreign Source Income, 52 SMU L. REV. 455, 50812 (1999) (describing a proposal for a real worldwide system); see also Fleming, Peroni \& Shay, Formulary Apportionment, supra note 7, at 18-20 (describing elements of a real worldwide system).

95. See Staff of Joint Comm. on TAXation, JCX-141R-15, Estimates of Federal TAX EXPENDITURES FOR FISCAL YEARS 2015-2019, at 29 (2015) (estimating a \$563.6 billion revenue loss over the 2015-2019 period from deferral of U.S. tax on active foreign income).

96. For discussion of the treaty compatibility of the U.K. and Australian permanent establishment enhancing initiatives, discussed at text accompanying supra notes 83-84, see Herzfeld, supra note 84, at 290-91; Hughes, Miller, Shiers \& Lane, supra note 83, at 40; Sapirie, supra note 83, at 303-04; Wagman, supra note 83, at 1428-31.

97. Customary international law does not require that countries use the permanent establishment concept as the jurisdictional threshold for imposing source tax on business income. See Schön, supra note 1, at 100. Indeed, the United States uses the lower threshold of "trade or business" when a treaty is not applicable. See I.R.C. $\S \S 871(b), 882$ (a) (2012). 
United States is in no position to object and, indeed, is free to employ similar measures in its own interest.

More importantly, if the United States were to eliminate or restrict its foreign tax credit in response to the negative effects on its residence taxation regime that might flow from the permissible source tax enhancement efforts of foreign countries, the U.S. conduct would constitute a breach of treaty obligations. ${ }^{98}$ Such a breach, in turn, could engender strategic foreign responses that would make this approach inadvisable.

In summary, the present and prospective efforts by foreign countries to strengthen their source tax regimes do not cast serious doubt on the soundness of the foreign tax credit as an approach to relieving international double taxation. In addition, so long as a U.S. residual tax remains to be collected after allowing a credit for foreign source tax, the U.S. fisc is better off than it would be if the United States moved to a territorial system and totally surrendered its claim to residual tax.

\section{Minimizing Foreign TAXES}

\section{A. Introduction}

The foreign tax credit causes each dollar of creditable foreign income tax liability to reduce the U.S. residual tax on foreign income up to the credit limit. Some foreign tax credit critics regard this as problematic because higher foreign tax liabilities mean less residual tax collected by the United States. The U.S. interest, so the argument goes, lies in having its residents engage in planning steps that minimize their foreign tax liabilities and maximize their U.S. residual tax payments. ${ }^{99}$ The foreign tax credit is regarded by these critics as seriously flawed because its allowance of an equal reduction in U.S. tax for each dollar of foreign tax liability, up to the limitation, is said to make U.S. taxpayers unmotivated to execute foreign tax minimization strategies when the effective foreign tax rate does not exceed the taxpayer's effective U.S. tax rate. ${ }^{100}$ Example 3 illustrates this point.

Example 3: AmeriCo is a Delaware corporation that has a $35 \%$ U.S. effective income tax rate. It carries on business in Country A where its effective income tax rate is $34 \%$. Assuming that the Country A tax is

98. See 2016 U.S. ModEL, supra note 9, art. 23.

99. See sources cited supra note 33.

100. See sources cited supra note 33 . 
creditable for U.S. purposes, every dollar of Country A tax that is paid will cause an offsetting dollar of reduction in U.S. tax. On the other hand, every dollar of Country A tax saved by AmeriCo through tax planning will reduce AmeriCo's foreign tax credit by one dollar and thereby increase AmeriCo's liability for U.S. residual tax by one dollar. Given those facts, it makes no sense, so the argument goes, for AmeriCo to incur tax planning costs to lawfully minimize its Country A tax, and AmeriCo will pay the full $34 \%$ Country A tax rather than create U.S. residual tax liability by taking steps to reduce the foreign tax.

Of course, if the United States reduces its corporate tax rate to a level comparable to that of most developed countries, there will be no meaningful U.S. residual tax except with respect to tax haven income. Thus, this point will lose its significance because minimization of low tax haven taxes is immaterial. However, this point should be evaluated in the context of the present $35 \%$ maximum U.S. statutory corporate income tax rate. To do so, it is necessary to think carefully about the extent of the foreign tax minimization opportunities that might be forgone because of the foreign tax credit. Under the present U.S. international income tax system that allows deferral of active foreign income and virtually unlimited cross-crediting, the largest, most transactionally complex, and expensive opportunity for reducing foreign taxes lies in creating stateless or homeless income. ${ }^{101}$ Example 4 illustrates this well-known technique in simplified terms.

\section{B. Stateless/Homeless Income}

The following simplified example illustrates the stateless/ homeless income concept.

Example 4: USCorp, a Delaware corporation subject to a U.S. effective tax rate of $35 \%$, is a multinational corporation (MNC) that owns all the stock of EuroSub, a foreign corporation. EuroSub is resident in European Country B where its effective tax rate is $25 \%$, and there is no withholding tax on outbound payments. USCorp causes EuroSub to create a wholly owned business organization in tax haven Country $\mathrm{C}$ that has no income tax. This organization is treated as a disregarded entity ${ }^{102}$ under U.S. tax law but as a juridical entity under the tax laws of both Country B and the tax haven Country C. EuroSub transfers important foreign business intangibles to the tax haven entity, which

101. See generally Kleinbard, Stateless Income, supra note 17 (explaining the creation and effect of stateless income); Wells \& Lowell, supra note 88 (same).

102. SeeTreas. Reg. $\S \S 301.7701-2(a),-3$ (a) (2006). 
licenses them to EuroSub in return for large royalty payments that are the maximum allowable under transfer pricing law and that are deductible as EuroSub business expenses under Country B law. The tax haven entity also loans money to EuroSub in return for interest payments that are the maximum allowable under transfer pricing law and that are deductible by EuroSub under Country B law.

The arrangement in Example 4 does not create any Subpart $\mathrm{F}$ income, ${ }^{103}$ but the Country B deductions reduce EuroSub's foreign taxes by effectively moving much of EuroSub's income from Country B's tax base to the tax haven Country C. ${ }^{104}$ In theory, this reduction in Country B tax liability will produce greater U.S. tax when dividends ultimately flow from EuroSub to USCorp because there will be less foreign tax to be credited against U.S. tax. ${ }^{105}$ The U.S. foreign tax credit, however, allegedly gives USCorp an incentive to avoid the planning and transactional costs of this foreign tax minimization tactic because dividends directly from EuroSub to USCorp will generate a U.S. deemed-paid tax credit that will effectively eliminate the $25 \%$ Country B tax on the shifted income without the tax haven rigmarole. ${ }^{106}$

Nevertheless, U.S. MNCs currently engage extensively in the tax planning illustrated in Example 4 even though the U.S. foreign tax credit should be incentivizing them to avoid it. ${ }^{107}$ This may be due to

103. Subpart F income is defined in I.R.C. $§ 952$ (2012). Generally speaking, U.S. shareholders owning directly, indirectly, or constructively $10 \%$ or more of the voting stock of a controlled foreign corporation are subject to current U.S. taxation on their shares of the foreign corporation's Subpart F income. See id. § 951. A foreign corporation is a controlled foreign corporation if more than $50 \%$ of the voting power or value of its stock is owned by such U.S. shareholders. See id. $\S 957$ (a). For a detailed discussion of these provisions, see 1 Kuntz \& PERONI, supra note 5, ch. B3. In Example 4, the fact that the Country C organization is a disregarded entity for U.S. tax purposes means that EuroSub's payments to it are ignored and do not create income, including Subpart F income.

104. Another arrangement for shifting income from high-tax to low-tax foreign countries is the "principal structure." For a description, see JOINT COMM., TAXATION OF CROSS-BORDER INCOME, supra note 76, at 52.

105. See Mike Cooper, Gary Melcher \& Clint Stretch, Suddenly Saving Foreign Taxes is Abusive? An Untenable Proposal, 79 TAX Notes 885, 888 (1998).

106. See I.R.C. $\S \S 902,960$. For a detailed discussion of these provisions, see 1 KUNTZ \& PERONI, supra note 5, ch. B4. Example 4 is a simplified version of the disregarded entity strategy. For a description of the full measure of its complexity, see Kleinbard, Stateless Income, supra note 17, at 706-13.

107. See Harry Grubert, Foreign Taxes and the Growing Share of U.S. Multinational Company Income Abroad: Profits, Not Sales, Are Being Globalized, 65 NAT'L TAX J. 247, 249, 251 (2012) (analysis of tax return data for 865 large U.S. multinational corporations shows that their average foreign effective tax rate declined by 5 percentage points from 1996 to 2004 and that use of disregarded entities "seems to have accounted for 1 to 2 percentage points of the 5.0 percentage point decline"); Kleinbard, Stateless Income, supra note 17, at 
the fact that the Country B tax would have to be paid currently, whereas much of EuroSub's profits are likely to be invested indefinitely offshore so that the benefit from credits for the $25 \%$ Country B tax would be significantly deferred and thus potentially diminished in value. ${ }^{108}$ Whatever the reason, the tax minimization strategy shown in Example 4 is a major reducer of the foreign tax liabilities of U.S. MNCs, ${ }^{109}$ and the alleged disincentive of the U.S. foreign tax credit does not seem to do much to discourage the use of the strategy.

Things would likely change if the United States were to adopt a real worldwide, or full inclusion, system under which (1) deferral was abolished; (2) the income of controlled foreign subsidiaries was subject to a current U.S. tax with a credit for foreign taxes; and (3) cross-crediting was severely limited. In this scenario, the tax planning that creates zero-taxed foreign income in Example 4 would seem to be truly pointless because the income would bear an immediate, full U.S. tax even if it were permanently reinvested off shore. $^{110}$ The manufacturing of stateless or homeless income seemingly would end, and in the context of Example 4, the U.S. tax "take" would surely be limited to the 10 percentage point excess of the $35 \%$ U.S. tax over the U.S. credit for the $25 \%$ Country B tax.

Should USCorp's abandonment of the strategy to minimize foreign taxes in Example 4 by moving income from high-tax Country $\mathrm{B}$ to tax haven Country $\mathrm{C}$ be regarded as unfortunate so far as the United States is concerned? We think not. At a time when the United States is acting to protect its own tax base by seeking the assistance of other countries and their resident financial institutions to gather information regarding the foreign-source income of U.S. residents, it would seem counterproductive to encourage U.S. residents to erode

737-50; see also CBO, OPTIONS FOR TAXING, supra note 7, at 14-17 (discussing profit shifting techniques and their effects); IMF, supra note 3, at 17 (same).

108. See Sheppard, supra note 92 (reviewing a 2015 report by Moody's, Inc. showing that cumulative foreign earnings reported as permanently invested offshore were $\$ 93$ billion for Microsoft, $\$ 70$ billion for Apple, $\$ 47$ billion for Google, and $\$ 74$ billion for Pfizer). Professor Shaviro observes that under the so-called new view of dividends, assuming eventual repatriation and constant tax rates, deferral will not result in diminished present value of foreign tax credits. Shaviro, supra note 33 , at 83-85. He continues, however, to point out that in practice these assumptions do not generally hold. Accordingly, deferral introduces risk that foreign tax credits will not be fully utilized or otherwise not maintain their full value. Id. at 85-87.

109. See sources cited supra note 107.

110. See KeIGHTLEY \& STUPAK, supra note 28, at 15. 
the tax bases of those countries with the stateless/homeless income strategy illustrated in Example 4.

At this point, it is worth noting that it is disingenuous to argue that because the foreign tax credit allegedly makes U.S. residents indifferent to maximizing U.S. residual tax by minimizing foreign taxes, the U.S. foreign tax credit should be replaced with an exemption or territorial system. An exemption system would totally eliminate the U.S. residual tax on foreign-source active income. Granted, U.S. residents would then be highly incentivized to minimize foreign taxes but that is only because there would be no U.S. tax. Thus, foreign tax minimization strategies would not have any positive effect on U.S. revenue. Concerns about protecting the U.S. residual tax on active income are irrelevant under a territorial system.

Finally, some commentators seem to treat foreign taxes paid by U.S. residents as having a zero positive effect on U.S. welfare. ${ }^{11}$ This view is overstated and wrong. It is obviously in the U.S. national interest to have a world of functioning nation states. Whether foreign tax revenue goes to absorb refugees that otherwise would come to the United States, shoulder a larger portion of NATO defense costs, or avoid the clear and present danger to the United States of a failed state and the resulting need for military intervention, tax revenues paid to a foreign sovereign that is not an enemy of the United States have more than zero marginal utility for the United States and its residents. It is doubtful that U.S. interests are served by incentivizing U.S. MNCs to employ tax minimization strategies, such as those in Example 4, that impair the fiscal foundations and social contracts of those states. ${ }^{112}$

\section{Elective Benefits Under Foreign Income Tax Systems}

With the Example 4 structure out of the way, the remaining strategies for reduction of foreign taxes would seem to be internal to foreign systems, such as taking advantage of provisions that allow taxpayers to defer income, accelerate deductions, and qualify for tax expenditures. The costs of securing these benefits are often not very high. It is unlikely that the U.S. foreign tax credit would cause U.S. taxpayers to forgo such benefits in favor of claiming larger U.S.

111. See sources cited supra note 33

112. See generally OECD, Action Plan, supra note 82, at 8 (detailing the harmful effects that flow from U.S. MNCs minimizing their tax burdens); Reuven S. Avi-Yonah, Globalization, Tax Competition, and the Fiscal Crisis of the Welfare State, 113 HARV. L. REV. 1573 (2000) (same). 
foreign tax credits that are potentially subject to disputes with the IRS on various grounds. ${ }^{113}$

\section{Choosing Between Foreign Countries}

However, there is one other point to consider regarding the interaction of the U.S. foreign tax credit and the income taxes imposed by other countries. It is illustrated by Example 5 .

Example 5: USCorp, a Delaware corporation, bears a U.S. effective tax rate of $35 \%$. It has exhausted U.S. investment opportunities that produce competitive returns and is considering expanding by building a new factory in either Country D or Country E. Both factories will require a $\$ 10$ million investment, but the Country $\mathrm{D}$ factory would yield an annual $20 \%$ before-tax return $(\$ 2,000,000)$ while the Country E factory's annual before-tax return would be only $15 \%(\$ 1,500,000)$. However, the Country D effective tax rate would be $30 \%$ while the Country E effective tax rate would be zero because Country E would grant a tax holiday for the expected life of the new factory.

On these facts, the Country D factory is the economically superior investment by 5 percentage points $(\$ 500,000)$. When foreign taxes are taken into account $(\$ 600,000$ in Country D and zero in Country E), however, the Country D after-foreign-tax return drops to $14 \%(\$ 1,400,000)$, while the Country $\mathrm{E}$ after-foreign-tax return equals the $15 \%(\$ 1,500,000)$ before-tax return. Without U.S. income tax, USCorp would build the new factory in Country E, which would be bad for the world economy because it would lose 5 percentage points of economic value creation. Nevertheless, as the argument goes, this would be good for the United States because an American corporation would be earning a $15 \%$, instead of $14 \%$, after-foreign-tax return on a $\$ 10$ million investment. ${ }^{114}$

Things change if we assume a U.S. tax system with a foreign tax credit and no deferral. In that case, there would be a 5\% U.S. residual tax $(\$ 100,000)$ on the Country D return (reducing it to $13 \%$ or $\$ 1,300,000$ ) and a $35 \%$ U.S. residual tax on the Country E return (dropping it to $9.75 \%$ or $\$ 975,000$ ), and USCorp would go with the Country D factory. Purely in terms of results after foreign taxes but before U.S. taxes, this would result in a $\$ 100,000$ economic loss $(\$ 1,500,000-\$ 1,400,000)$ to USCorp and to U.S. national well-being.

113. See Treas. Reg. $§ 1.901-2$ (2006) (detailing requirements that must be met in order for a foreign tax to qualify as a creditable income tax).

114. See Viard, supra note 33, at 560-61. 
On the other hand, if the United States employed a territorial system, there would be no U.S. residual tax, the relevant after-foreigntax returns would remain at $15 \%$ for the Country E factory and $14 \%$ for the Country D factory, and USCorp would locate the factory in Country E.

Alan D. Viard of the American Enterprise Institute has argued that the appropriate analysis should focus on after-foreign-tax results. ${ }^{115}$ Under that approach, Viard asserts that locating the factory in Country $\mathrm{E}$ is the better result from a U.S. perspective because it results in USCorp, "our" national champion, enhancing our national well-being by earning a greater after-foreign-tax return than otherwise. ${ }^{116}$

Although this conclusion is rigorously reasoned, it overlooks the revenue effect. Under a worldwide system without deferral and crosscrediting, USCorp will choose the investment in Country D that will yield a 5\% residual tax for the United States. In contrast, if the United States adopts a territorial system to induce USCorp to make the Country E investment, the U.S. residual tax will be zero.

This conclusion is also questionable from an additional perspective. On the facts of Example 5, the 35\% U.S. residual tax is the factor that tips USCorp away from Country E's 15\% after-foreigntax return. Thus, the national champion argument calls for absolving USCorp from the residual tax that the United States is entitled to impose under customary international law. As we have explained in earlier work, this argument amounts to a plea for an inefficient tax subsidy, analogous to the inefficiency of an export subsidy. Such subsidies are inefficient, even if other countries grant them to their national champions. ${ }^{117}$

But if such tax subsidies were granted to USCorp and all other U.S. MNCs that find themselves in situations similar to Example 5, would the economic benefit to those MNCs create sufficient spillover benefits to the U.S. economy to make the subsidies worthwhile? The recent evidence suggests that the answer is no.

As we have explained in prior work, because of deferral and cross-crediting, U.S. MNCs already largely escape U.S. residual tax on their foreign-source income and thereby receive a de facto

115. See id.

116. See id.

117. See David Brumbaugh, Export Tax Subsidies, in The EnCyClopedia OF TAXATION \& TAX POLICY 130, 132 (Joseph J. Cordes, Robert D. Ebel \& Jane G. Gravelle eds., $2 d$ ed. 2005); McDaniel, supra note 55, at 1624-25. 
subsidy. ${ }^{118}$ But the result has not been a cornucopia of new U.S. jobs. ${ }^{119}$ More narrowly, in 2004 Congress enacted a provision that waived most of the U.S. residual tax on foreign income repatriated within a limited time window in 2004 and 2005. ${ }^{120}$ During congressional development of this legislation, advocates argued that it would result in large amounts of previously untaxed earnings being brought home to U.S. MNCs that would use the funds for domestic business expansions and that such expansions would, in turn, create domestic jobs. ${ }^{121}$ Economic studies have, however, uniformly found that the foreign income repatriated under this provision was principally used to finance dividends, stock redemptions, and corporate acquisitions, all of which primarily benefit upper-income taxpayers. ${ }^{122}$ The predicted explosion of domestic jobs from corporate expansion did not occur. ${ }^{123}$ This evidence combines to cast

118. See Fleming \& Peroni, Reinvigorating Tax Expenditure Analysis, supra note 58, at $528-61$.

119. The Staff of the Joint Committee on Taxation has stated:

There is no definitive conclusion about the effect of outbound investment on U.S. employment. [A survey of the empirical literature] concludes, "[T] he evidence suggests that the effect of overseas production on the home-country labor market involves the composition of a firm's home employment rather than the total amount. That change in composition is mainly a shift toward more managerial and technical employment ...."

Joint Comm., Alternative Policies, supra note 21, at 20 (quoting Robert E. Lipsey, Outward Direct Investment and the U.S. Economy 38 (Nat'l Bureau of Econ. Research, Working Paper No. 4691, 1994)) (internal quote immaterially modified in ALTERNATIVE POLICIES); see Grubert, supra note 107, at 278 ("The positive effects implied by the 'low tax burdens on foreign income are good for domestic investment' argument and the negative effects implied by the 'export of jobs' argument seem to cancel."); see also Martin A. Sullivan, U.S. Multinationals Cut U.S. Jobs While Expanding Abroad, 128 TAX NoTES 1102, 1102 (2010) (stating that low job growth in the United States is correlated to the rise in U.S. MNCs' robust overseas hiring practices); Scott Thurm, U.S. Firms Add Jobs, But Mostly Overseas, Wall St. J., Apr. 27, 2012, at B1 (same); Sudeep Reddy, Domestic-Based Multinationals Hiring Overseas, WALL ST. J. (Apr. 18, 2013, 4:08 PM), http://www.wsj.com/articles/SB10001 424127887324763404578430960988848252 (same). 27.

120. See JoInt COMM., IMPACT OF InTERNATIONAL TAX REFORM, supra note 9, at 26-

121. See J. Clifton Fleming, Jr. \& Robert J. Peroni, Eviscerating the U.S. Foreign Tax Credit Limitations and Cutting the Repatriation Tax-What's ETI Repeal Got to Do With It?, 35 TAX NOTES INT'L 1081, 1099-1100 (2004).

122. See Justin Bryan, Individual Income Tax Returns, 2011, in IRS STATISTICS OF INCOME BULLETIN 23 (Fall 2013) (showing dividend income, and therefore stock ownership, concentrated among high-income individuals); Roy Clemons \& Michael R. Kinney, $A n$ Analysis of the Tax Holiday for Repatriation Under the Jobs Act, 120 TAX NOTES 759 (2008) (discussing that repatriated funds were used principally for stock repurchases).

123. See Martin A. Sullivan, Repatriation Holiday Would Destroy American Jobs, 129 TAX NOTES 759 (2010). 
considerable doubt on the proposition that relieving U.S. MNCs from U.S. residual tax will produce sufficient domestic economic benefits to justify the tax subsidy. ${ }^{124}$ Moreover, using a tax subsidy in Example 5 to cause USCorp to locate the factory in Country $\mathrm{E}$ is an intervention deliberately crafted to cause USCorp to choose the economically inferior investment. Paying U.S. corporations to switch from superior to inferior options is facially wasteful and ought not to be done without strong empirical support of substantial benefits to the U.S. economy that has not been produced.

\section{E. Replacing the Foreign Tax Credit with a Combination of a Deduction and a Preferential Tax Rate: A Response to Professor Shaviro}

In our judgment, the preceding discussion in this Part IV has shown that the alleged negative impact of the U.S. foreign tax credit on decisions by U.S. residents to engage in foreign tax credit minimization strategies is not a significant issue. To the extent it is a bona fide concern, Professor Daniel Shaviro has proposed responding by replacing the U.S. foreign tax credit with a deduction for foreign taxes and pairing this deduction with a U.S. tax rate on foreign income that is reduced to a level just low enough to mitigate the double taxation that would otherwise result. ${ }^{125}$ His idea has undergone progressive development. ${ }^{126}$ In its most recent iteration, Professor Shaviro proposes (1) replacement of the foreign tax credit with a foreign tax deduction, (2) a low U.S. tax rate on a taxpayer's entire foreign-source income if that income bears a sufficient overall foreign tax rate, (3) a more substantial, but less than normal, U.S. tax on a taxpayer's entire foreign-source income if that entire income bears no foreign tax, and (4) a sliding scale of U.S. rates for total foreign income that falls between (2) and (3). ${ }^{127}$

Professor Shaviro has explained that the top, bottom, and interim U.S. tax rates in his proposal would be set to yield the same after-U.S.tax return that the taxpayer would enjoy on worldwide foreign-source income if the United States continued to use the foreign tax credit. $\mathrm{He}$ and a coauthor have provided the following formula for

124. See supra notes $119,122,123$, and accompanying text.

125. See Daniel N. Shaviro, Rethinking Foreign Tax Creditability, 63 NAT'L TAX J. 709, 717 (2010).

126. See id:; Kimberly Clausing \& Daniel Shaviro, A Burden-Neutral Shift from Foreign Tax Creditability to Deductibility?, 64 TAx L. REv. 431 (2011).

127. See SHAVIRO, supra note 33, at 192. 
calculating the appropriate U.S. rates where tus represents the taxpayer's normal U.S. rate and $t f$ represents the taxpayer's overall foreign tax rate:

$$
\text { Appropriate U.S. rate }=\frac{(\mathrm{tus}-\mathrm{tf})^{128}}{(1-\mathrm{tf})}
$$

The critical elements of the proposal cut in opposite directions. Specifically, a foreign tax deduction, instead of a credit, gives relief from foreign taxation only to the extent of the foreign tax liability multiplied by the taxpayer's U.S. marginal tax rate. Thus, the deduction creates a partial double tax barrier to international business and investment. ${ }^{129}$ But since it gives only partial relief from double taxation, it loses less revenue than does a foreign tax credit or an exemption system. On the other hand, a reduced rate of tax on foreign-source income amounts to a partial exemption system ${ }^{130}$ that subsidizes U.S. residents who locate new business and investment activities in low-tax countries rather than in the United States; this creates a tax revenue loss when compared to a real worldwide system. ${ }^{131}$ Example 6 explores how the opposing effects of Professor Shaviro's proposal would net out.

Example 6: Corporate tax reform has occurred and USCorp, a Delaware corporation, bears a U.S. effective tax rate of $25 \%$. Also, the United States has replaced the foreign tax credit with a foreign tax deduction coupled with reduced rates on foreign-source income that are derived from Professor Shaviro's formula set forth above. USCorp is contemplating the following foreign investments that require equal amounts of capital:

\section{Foreignlandia}

Investment 1: $\$ 100$ before-tax return if made in the United States and $\$ 95$ before-tax return if made in Foreignlandia

Investment 2: $\$ 95$ before-tax return if made in the United States and $\$ 100$ before-tax return if made in Foreignlandia

128. See Clausing \& Shaviro, supra note 126, at 435-38.

129. See supra text accompanying notes 66-71.

130. See Shay, Fleming \& Peroni, Designing a 21st Century Corporate Tax, supra note 88, at 708-09. To illustrate, if the regular U.S. tax rate is $25 \%$ but the United States imposes a $10 \%$ tax on foreign-source income, the effect is the same as exempting $60 \%$ of the taxpayer's foreign-source income and taxing the remaining $40 \%$ at the regular $25 \%$ rate $([\$ 0.60 \times 0]+$ $[\$ 0.40 \times .25]=\$ 1.00 \times .10)$.

131. See sources cited supra note 28 . 
Otherlandia

Investment 3: $\$ 100$ before-tax return if made in the United States and $\$ 95$ before-tax return if made in Otherlandia.

Investment 4: \$95 before-tax return if made in the United States and $\$ 100$ before-tax return if made in Otherlandia.

Assume that (1) Foreignlandia has no income tax, (2) US Corp's effective tax rate in Otherlandia would be $20 \%$, (3) USCorp's overall foreign effective tax rate would be $10 \%$, and (4) the U.S. rate imposed on all of its foreign-source income under Professor Shaviro's proposal would be $16.67 \%{ }^{132}$ To simplify, also assume that the U.S. tax applies on a current basis; that is, there is no deferral.

Because Foreignlandia imposes a zero tax, there will be no foreign tax to be deducted in the Foreignlandia scenario. Instead the critical factor with respect to Investments 1 and 2 will be the difference between the assumed 25\% U.S. tax on domestic-source income and the $16.67 \%$ U.S. tax that would be levied on Foreignlandia-source income under Professor Shaviro's proposal. Table 1 shows the results under Professor Shaviro's proposed system.

\section{Table 1}

$\begin{array}{cc}\text { After-Tax } & \text { After-Tax } \\ \text { Return in } & \text { Return in } \\ \text { United States } & \text { Foreignlandia }\end{array}$

Investment 1 Before-

Tax Return

(\$100 U.S./\$95

$\$ 75^{133} \quad \$ 79.16^{134}$

Foreignlandia)

Investment 2 Before-

Tax Return

(\$95 U.S./\$100

$\$ 71.25^{135} \quad \$ 83.33^{136}$

Foreignlandia)

In terms of worldwide economic welfare, USCorp should make Investment 1 in the United States and Investment 2 in Foreignlandia because those locations yield the higher before-tax returns $(\$ 100$ each). From this standpoint, Professor Shaviro's proposal achieves the

132. $(.25-.10) \div(1-.10)=.1667$, using the formula quoted in the text.

133. $\$ 100 \times(1-.25)=\$ 75$.

134. $\$ 95 \times(1-.1667)=\$ 79.16$.

135. $\$ 95 \times(1-.25)=\$ 71.25$.

136. $\$ 100 \times(1-.1667)=\$ 83.33$. 
wrong result with respect to Investment 1 because the higher after-tax return for the Foreignlandia location will cause Investment 1 to be made there. ${ }^{137}$ The U.S. before-tax return on Investment 1 would have to exceed $\$ 105.55$ to get the correct location result. ${ }^{138}$

In comparison, a U.S. worldwide system with a foreign tax credit, no deferral, and a $25 \%$ U.S. tax on both domestic and foreign income would give Investment 1 after-tax returns of $\$ 75^{139}$ in the United States and $\$ 71.25^{140}$ in Foreignlandia and would give Investment 2 after-tax returns of $\$ 71.25^{141}$ in the United States and $\$ 75^{142}$ in Foreignlandia. Thus, USCorp would locate both investments correctly-Investment 1 in the United States and Investment 2 in Foreignlandia. Professor Shaviro's proposal, however, induces USCorp to put Investment 1 in Foreignlandia - the wrong placethereby causing the United States to substitute a $16.67 \%$ tax on $\$ 95$ $(\$ 15.84)$ for a $25 \%$ tax on $\$ 100(\$ 25)$. This $\$ 9.16$ revenue loss is effectively a subsidy to USCorp for choosing an inferior investment in a foreign country. The wisdom of such a subsidy is elusive. ${ }^{143}$

Turning to Investment 2, a worldwide system with a $25 \%$ U.S. tax rate, a foreign tax credit, and no deferral would cause the United States to collect $\$ 25$ of residual tax revenue from the Foreignlandialocated investment ${ }^{144}$ (which bears zero Foreignlandia tax). In contrast, there would be only $\$ 16.67$ of residual $\operatorname{tax}^{145}$ in the Investment 2 scenario under Professor Shaviro's proposal. This $\$ 8.33$ revenue loss is effectively a subsidy to USCorp for making a Foreignlandia investment that it would have made without subsidization. This is so because even under Professor Shaviro's approach, an $\$ 8.33$ reduction in the Investment 2 after-tax return

137. Even those who take a pure national welfare view would regard a Foreignlandiabased Investment 1 as being in the wrong location because it is not in the United States. See JOINT COMM., IMPACT OF INTERNATIONAL TAX REFORM, supra note 9, at 59-60; Viard, supra note 33 , at 560-62, 564. U.S. multinational corporations would, however, regard Investment 1 as being in the right place because the Foreignlandia location produces the greater after-tax return.

138. $\$ 105.55 \times(1-.25)=\$ 79.16$.

139. $\$ 100 \times(1-.25)=\$ 75$.

140. $\$ 95 \times(1-.25)=\$ 71.25$.

141. $\$ 95 \times(1-.25)=\$ 71.25$.

142. $\$ 100 \times(1-.25)=\$ 75$.

143. In other work, we have explained why the competitiveness argument does not support this subsidy. See Fleming, Peroni \& Shay, Perspectives, supra note 26, at 1085-86.

144. $\$ 100 \times .25=\$ 25$.

145. $\$ 100 \times .1667=\$ 16.67$. 
would leave Foreignlandia as the superior after-tax location. ${ }^{146}$ Thus, the subsidy for Investment 2 makes no sense unless one accepts the contention that it is necessary to make USCorp's Investment 2 competitive in the Foreignlandia market.

In earlier work, we have explained why the competitiveness argument is unsound. ${ }^{147}$ Here we add the observation that although Professor Shaviro's proposal subsidizes USCorp's Investment 2 to the extent of $\$ 8.33$, it nevertheless imposes a $\$ 16.67$ residual tax on that investment. Because there is no foreign tax credit, this tax cannot be reduced by cross-crediting. For anyone who has embraced the competitiveness view, which we do not suggest includes Professor Shaviro, this is an unacceptable result because it allegedly makes USCorp's Investment 2 noncompetitive against equivalent Foreignlandia investments made by multinational corporations that are resident in territorial system countries and therefore pay no residual tax on their Foreignlandia income. ${ }^{148}$ More broadly, because Professor Shaviro's proposal applies a preferential, but positive, tax rate to foreign-source income, the result is always a positive U.S. residual tax. This is inconsistent with the zero U.S. residual tax required by the standard iteration of the competitiveness argument. Under that standard iteration, any positive U.S. residual tax is anticompetitive. ${ }^{149}$ Interestingly, Professor Shaviro's proposal has its greatest impact in the zero foreign tax situation because his formula causes the U.S. residual tax rate to increase as the foreign tax rate decreases. For true believers in the competitiveness argument, the only attraction of Professor Shaviro's proposal is that a U.S. residual

146. $\$ 83.33-\$ 8.33=\$ 75$, as compared with a $\$ 71.25$ after-tax return in the United States.

147. See Fleming, Peroni \& Shay, Perspectives, supra note 26, at 1085-87; see also KeIGHTLEY \& StUPAK, supra note 28, at 16 (explaining that competitiveness is a flawed criterion).

148. See NFTC 1, supra note 31, at 12; Kimberly A. Clausing, Beyond Territorial and Worldwide Systems of Taxation, 15 J. INT'L FIN. \& ECON. 43, 50 (2015).

149. See NFTC 1, supra note 31, at 12. Some territorial systems, however, do not allocate headquarters' expenses to foreign subsidiaries. Instead, they allow headquarters' expenses that benefit foreign subsidiaries to be deducted against domestic income, while imposing a small tax on dividends received from subsidiaries as a rough proxy for the forgone allocation. In such a case, the small tax is effectively offset (perhaps even more than offset) by the benefit of larger-than-appropriate deductions against taxable U.S.-source income. See JoInt Comm., BACKGROUND AND Issues, supra note 8, at 23, 25; Rosanne Altshuler, Stephen Shay \& Eric Toder, Lessons the United States Can Learn from Other Countries' Territorial Systems for Taxing Income of Multinational Corporations, TAX POL'Y CTR. 26 (Jan. 21, 2015), www.taxpolicycenter.org/sites/default/files/alfresco/publicationpdfs/2000077-lessons-the-us-can-learn-from-other-countries.pdf. 
tax at a reduced rate is better than a U.S. residual tax at the regular rate.

The Otherlandia scenario in Example 6 introduces the assumption of a $20 \%$ Otherlandia effective tax rate and continues to assume a $25 \%$ U.S. rate on domestic income and a $16.67 \%$ U.S. rate on foreign-source income. The results under Professor Shaviro's proposed system are shown in Table 2 .

Table 2

$\begin{array}{cc}\text { After-Tax } & \text { After-Tax } \\ \text { Return in } & \text { Return in } \\ \text { United } & \text { Otherlandia } \\ \text { States } & \end{array}$

Investment 3 Before-Tax

Return $\$ 75^{150}$ $\$ 63.33^{151}$

(\$100 U.S./\$95 Otherlandia)

Investment 4 Before-Tax

Return $\$ 71.25^{152} \quad \$ 66.66^{153}$

(\$95 U.S./\$100 Otherlandia)

Here, Professor Shaviro's proposal gets the correct location for Investment 3 but not Investment 4 . Investment 3 should be made in the United States, and Investment 4 should be made in Otherlandia because those are the locations with the superior before-tax returns. As Table 2 shows, however, both investments will be made in the United States because that is where both yield higher after-tax returns. With respect to locating Investment 4 in Otherlandia, Professor Shaviro's substitution of a \$20 U.S. foreign tax deduction (worth \$20 $\times .1667=\$ 3.33$ ) for a $\$ 20$ U.S. foreign tax credit (worth \$20) creates a \$16.67 tax "loss" for USCorp that outweighs the gains that it would

150. $\$ 100 \times(1-.25)=\$ 75$.

151. $\$ 95 \times .20=\$ 19$ Foreignlandia tax.

$\$ 95-\$ 19=\$ 76$ U.S. tax base.

$\$ 76 \times .1667=\$ 12.67$ U.S. tax.

$\$ 95-\$ 19-\$ 12.67=\$ 63.33$ after-tax return in Foreignlandia.

152. $\$ 95 \times(1-.25)=\$ 71.25$.

153. $\$ 100 \times .20=\$ 20$ Foreignlandia tax.

$\$ 100-\$ 20=\$ 80$ U.S. tax base.

$\$ 80 \times .1667=\$ 13.34$ U.S. tax.

$\$ 100-\$ 20-\$ 13.34=\$ 66.66$ after-tax return in Foreignlandia. 
have from the greater before-tax return in Otherlandia and the below normal U.S. tax on Otherlandia-source income. ${ }^{154}$

Some might argue that there is nothing wrong with USCorp choosing a U.S. location for Investment 4 because having Investment 4 on U.S. soil instead of in Otherlandia makes the United States better off although the Otherlandia investment is economically superior. Is the United States advantaged by having USCorp own an inferior investment in the United States instead of a superior investment in Otherlandia? That is ultimately an empirical question which, to our best knowledge, has not generated a definitive empirical answer. Economic orthodoxy, however, holds that the U.S. taxing scheme that causes USCorp to forgo the Otherlandia location for Investment 4 is an inefficient allocation of resources and that it therefore is in the best interest of the United States to adopt rules that do not interfere with USCorp placing Investment 4 in Otherlandia. ${ }^{155}$ Professor Shaviro's proposal would frustrate that outcome.

Of course, USCorp's decision to make Investment 4 in the United States saved the Treasury from losing the difference between a $25 \%$ tax on $\$ 95$ and a $16.67 \%$ tax on $\$ 100$ minus the $20 \%$ Otherlandia tax thereon. ${ }^{156}$ This is an ambiguous fact though because the $16.67 \%$ tax represents a congressional policy decision to suffer any revenue loss that results from a below normal tax on foreignsource income.

The locational problems illustrated in Tables 1 and 2 arise because Professor Shaviro's formula produces a U.S. rate for foreignsource income that is based on the individual taxpayer's average effective rate on foreign-source income. As Tables 1 and 2 show, this approach produces imperfect results when the taxpayer earns, or has the opportunity to earn, foreign income in countries with rates that are significantly higher or lower than the taxpayer's average foreign effective tax rate. These problems would disappear if Professor Shaviro's system were applied on a country-by-country basis. ${ }^{157}$ But

154. The before-tax return advantage of the Otherlandia location is $\$ 100-\$ 95=\$ 5$. After Otherlandia and U.S. tax, this is worth $\$ 3.33$. The advantage from the below normal U.S. tax on the Otherlandia investment is $(\$ 80 \times .25)-(\$ 80 \times .1667)=\$ 6.66$. The sum of these advantages is $\$ 3.33+\$ 6.66=\$ 9.99$. The $\$ 16.67$ tax loss referred to in the text exceeds these advantages by $\$ 6.68$ ( $\$ 16.67$ - $\$ 9.99$ ). If this $\$ 6.68$ of excess loss had not been suffered, the after-tax return on Investment 4 in Otherlandia would have been $\$ 66.66+\$ 6.68=\$ 73.34$, and Investment 4 would have been made in Otherlandia.

155. See sources cited supra note 65 .

156. $(.25 \times \$ 95)-.1667[\$ 100-(\$ 100 \times .20)]=\$ 10.41$.

157. See Clausing \& Shaviro, supra note 126 , at $435-37$. 
he has concluded that doing so would be impractical. ${ }^{158}$ Consequently, we are left with the results of Tables 1 and 2 .

Generally speaking, Tables 1 and 2 show that Professor Shaviro's proposal is problematic in that it produces locational errors and dubious subsidies. Moreover, the problem that it seeks to solve-U.S. taxpayer indifference to minimizing foreign taxes in a foreign tax credit system - seems to be small. ${ }^{159}$ In addition, the proposal's rate distinction between foreign-source income and U.S.-source income would require prophylactic rules to deal with the responsive incomeshifting strategies that inevitably would be employed by taxpayers, and the proposal would place considerable pressure on the source and transfer pricing rules. Thus, Professor Shaviro's proposal would not be simple in practice. We are not persuaded that it is a superior alternative to a regime that employs a foreign tax credit without significant cross-crediting and that taxes foreign-source income at normal rates and without deferral.

If, however, the choice were limited to either Professor Shaviro's proposal or a territorial system, we would prefer Professor Shaviro's approach. In part, this is because the residual U.S. tax that it imposes makes it less costly to the fisc than a territorial system that, by definition, imposes no residual tax on foreign-source active income. More importantly, this absence of a residual tax in a territorial system increases the danger that U.S. residents will prefer investments in lowtax foreign countries even when they have a lower pretax rate of return than investments in the United States. ${ }^{160}$ On the other hand, if a real worldwide system (having a limited foreign tax credit, no deferral, and no significant cross-crediting) is included in the menu of choices, it is clearly our preferred option.

\section{The Foreign Tax Credit as Allocator of the INTERNATIONAL INCOME TAX BASE: COMMENTS ON INTERNATION EQUITY}

\section{A. Territorial Compared with Worldwide}

Some of the literature regarding allocation of the international income tax base assumes that the world's leading nations have surrendered (or should surrender) the right to tax their residents' worldwide business incomes so that only source taxation of business

158. See id. at 437.

159. See supra text accompanying notes 106-112.

160. See sources cited supra note 28 . 
income is relevant. ${ }^{161}$ Thus, this viewpoint posits that the world consists (or should consist) of countries that apply only source taxation to business income. From that standpoint, the process of allocating the international tax base is limited to requiring that each country identify the business income that is sufficiently connected with its territory to warrant application of its source tax regime. The principal alternatives for carrying out this source tax allocation exercise are an explicit territorial system that employs transfer pricing and source rules, ${ }^{162}$ a global formulary apportionment system, ${ }^{163}$ and various formulary hybrids. ${ }^{164}$

In prior work, we have explained why taxation of residents on their worldwide incomes, as is permitted by customary international law, ${ }^{165}$ should be practiced by the world's nations for reasons of fairness and efficiency. ${ }^{166}$ We therefore do not subscribe to a vision of the world that consists entirely of source country taxation. The United

161. See, e.g., Reuven S. Avi-Yonah, Kimberly A. Clausing \& Michael C. Durst, Allocating Business Profits for Tax Purposes: A Proposal To Adopt a Formulary Profit Split, 9 Fla. Tax Rev. 497 (2009); Adam H. Rosenzweig, Defining a Country's "Fair Share" of Taxes, 42 Fla. St. U. L. REV. 373 (2015); Sol Picciotto, Towards Unitary Taxation of Transnational Corporations, TAX JUST. NETWORK (2012), www.taxjustice.net/cms/upload/pdf/ Towards_Unitary_Taxation_1-1.pdf.

162. See Brian J. ARNOLD \& Michael J. MCInTYRe, InTERNATIONAL TAX Primer 35 (2d ed. 2002); JoINT COMM., BACKGROUND AND IssueS, supra note 8, at 11; PRESIDENT'S ADVISORY PANEL ON FED. TAX REFORM, supra note 22, at 134.

163. See Fleming, Peroni \& Shay, Formulary Apportionment, supra note 7, at 32-47.

We use the term "global formulary apportionment" to refer to the process of formulaically allocating a multinational corporate group's entire worldwide consolidated income among the source tax regimes of the countries in which it has activities instead of using source rules and transfer pricing principles to make the allocation. See id. In contrast, a formulary approach is sometimes used for the limited purpose of allocating only discrete types of income, such as intangibles income, within a worldwide system. See id. at 53-56.

In theory, global formulary apportionment could be used to distinguish foreign-source and domestic-source income (or discrete types of such income) for purposes of applying the U.S. foreign tax credit limitation. Global formulary apportionment supporters do not seem to have advocated this approach, however. See id. at 56; Peroni, supra note 57, at 1002-03 n.78.

164. See generally SHAVIRO, supra note 33, at 190 (proposing that foreign-source income be taxed but at a rate substantially below the generally applicable rate); Elizabeth Chorvat, Forcing Multinationals To Play Fair: Proposals for a Rigorous Transfer Pricing Theory, 54 ALA. L. REV. 1251 (2003) (proposing a formulary apportionment international tax regime based on location of assets and imputed returns); Rosenzweig, supra note 161 (proposing a formulary apportionment international tax regime based on "amenities" and returns to public goods).

165. See sources cited supra note 2 .

166. See generally Fleming, Peroni \& Shay, Perspectives, supra note 26 (arguing that a worldwide tax system is superior to a hybrid tax system in avoiding distortion, inefficiencies, and unfairness). 
States should continue to employ and enhance its worldwide taxation regime. ${ }^{167}$

From the standpoint of worldwide taxation, allocating the international income tax base is not limited to calculating the respective source taxation bases of the world's nations. It also involves allocating the base between residence countries and source countries. This, in turn, requires the identification of relevant allocation principles.

\section{B. Searching for Allocation Principles}

Certain familiar principles serve as fairness norms for allocating the tax burden among both a country's residents and the nonresidents who earn income within its borders. These principles include abilityto-pay, ${ }^{168}$ horizontal equity, ${ }^{169}$ vertical equity, ${ }^{170}$ and benefits received. ${ }^{171}$ Although the guidance these norms provide is not scientifically precise, they at least furnish a framework for debating the ethical component of domestic tax policy. ${ }^{172}$ Regrettably, these principles say nothing useful about how rights to tax international income should be allocated among residence countries and source countries. ${ }^{173}$

In the absence of clear normative guidance, ${ }^{174}$ we must default to the empirical fact that source countries are effectively positioned to tax income earned on their soil before residence country tax systems

167. See Fleming, Peroni \& Shay, Formulary Apportionment, supra note 7, at 18-19 (describing a robust, or "real," worldwide taxation regime).

168. See Fleming, Peroni \& Shay, Fairness in International Taxation, supra note 2, at 306-14.

169. See Dodge, Fleming \& Peroni, supra note 66, at 72.

170. See id. at 73 .

171. See id. at 74-75.

172. See generally Fleming, Peroni \& Shay, Fairness in International Taxation, supra note 2 (discussing how equity is analyzed, and often not analyzed, in relation to international tax policy).

173. See Corwin, supra note 1, at 136; Mindy Herzfeld, Tax Planning and Fairness in International Tax, 79 TAX NOTES INT'L 103, 104-05 (2015); Schön, supra note 1, at 72-78; see also Benshalom, supra note 1, at 72-73 (noting that there is little philosophical literature discussing internation equity in comparison to the literature discussing domestic redistribution); Li, supra note 1 , at 119 (discussing the difference between equity among individual taxpayers and equitable allocation of the tax base between nations).

174. Advocates for the interests of poor countries have argued that wealthy countries should aid poor countries, including possibly providing assistance through tax measures. We agree. See Benshalom, supra note 1 , at $67-81$; Li, supra note 1 , at 121,124 . However, those arguments have not yet created a recognized basis for asserting that poor countries have a normative right to some defined portion of the global tax revenues. See Christians, supra note 1, at 151; Ring, supra note 2, at 180-83, 225. 
can impose tax. ${ }^{175}$ Given this reality, it is not surprising that international law allows source countries the primary taxing right with respect to international income and that residence countries are limited to imposing a tax that is reduced to accommodate the prior source tax. ${ }^{176}$ As previously discussed, this accommodation is achieved either (1) by the residence country granting a foreign tax credit for the source country tax and collecting a residual tax to the extent that residence tax exceeds the source $\operatorname{tax}^{177}$ or (2) by the residence country adopting a territorial system under which it effectively waives its right to collect a residual tax on active income. ${ }^{178}$

Not only do these two approaches mitigate international double taxation, they also have "worked" for decades to allocate the international income tax base among the nations of the world. To be specific, the foreign tax credit approach recognizes the superior taxing right of source countries but only to the extent that a source tax is actually imposed. If the source country fails to tax up to the level of the residence country so that the residence tax exceeds the source tax, the foreign tax credit approach allows the residence country to capture the excess with a residual tax. ${ }^{179}$ Thus, the foreign tax credit effectively takes a "use it or lose it" approach to accommodating the source country's superior taxing right. In contrast, the territorial approach cedes taxing jurisdiction over active income to the source country regardless of the extent to which the source country actually uses its taxing power to raise revenue. ${ }^{180}$

175. As noted by Brian Arnold:

Whatever the theoretical justification for source-country taxation of business profits, in my opinion source countries will tax any business profits of nonresidents that they can tax effectively unless there is some good reason not to do so. The critical issue, therefore, is the practical enforcement of source-country taxation, not the theoretical justification for such tax.

Brian J. Arnold, Threshold Requirements for Taxing Business Profits Under Tax Treaties, in The Taxation of Business Profits Under Tax Treaties 55, 104 (Brian J. Arnold, Jacques Sasseville \& Eric M. Zolt eds., 2003); see also Ault \& Bradford, supra note 30, at 32 ("[F]orce majeure has been as important as any ethical conception of sovereignty in producing a general acceptance of the priority of the 'source' jurisdiction to tax particular transactions.").

176. See Restatement (ThiRd) of the Foreign Relations LaW of THE United States $§ 413 \mathrm{cmt}$. a (AM. LAW Inst. 1986); OECD, Model Tax Convention, supra note 6; U.N. Dep't of Econ. \& Soc. Aff., supra note 6; Brauner, supra note 6. Tax treaties, however, commonly reduce source taxes, thereby increasing the opportunities for residence countries to collect residual tax.

177. See sources cited supra note 10.

178. See sources cited supra note 7.

179. See sources cited supra note 11 .

180. See Li, supra note 1, at 127. 
Granted, this system means that residence taxation is at the "mercy" of source taxation. However, as explained in Parts III and IV, there are realistic constraints on source taxation that leave room for residence countries to collect a residual tax.

The tax base allocation regime that results from worldwide taxation and the foreign tax credit effectively eliminates international double taxation while upholding the principle of ability-to-pay and avoiding bias in favor of foreign investment. In contrast, territoriality encourages foreign countries to use low taxes to lure investment away from residence countries. This encouragement has particularly negative effects on low-income countries that are subjected to fierce competition for foreign investment and the important revenue it generates. By effectively imposing a "use it or lose it" rule on source countries, the foreign tax credit allows residence countries to defend themselves against this tax competition while also fully accommodating the normatively superior taxing rights of source countries. Indeed, there is no norm that requires residence countries to restrict their worldwide taxation rights in order to facilitate a source country's decision not to impose source tax. ${ }^{181}$ The foreign tax credit regime rejects such a restriction. In contrast, the territorial approach grants source countries a nontaxation right that produces the revenue loss and distortion consequences previously discussed in this Article. ${ }^{182}$

\section{The Plight of Developing Countries}

The flip side of the "use it or lose it" rule is that because the residence country's residual tax captures the excess of the residence tax over a low source country tax, a real worldwide system with a foreign tax credit deprives developing countries of the ability to achieve growth by using low taxes to lure investment away from developed countries that employ the foreign tax credit approach to international taxation. ${ }^{183}$ Professor Alexander Rust has refined this

181. See Benshalom, supra note 1, at 77-78 (lamenting the absence of such a norm); see also Christians, supra note 1, at 151 ("We may not yet (or ever) be in a position to discuss whether countries have a duty to redistribute income or otherwise seek global distributive justice through globally-oriented tax policy choices."); Schön, supra note 1, at 91 (“[T]ax jurisdiction is by no means restricted to income 'generated' in the territory of the taxing entity; worldwide taxation is customarily accepted under international law.").

182. See supra text accompanying notes 28-30.

183. See Benshalom, supra note 1, at 77; Elkins, supra note 50, at 927; Charles I. Kingson, The Coherence of International Taxation, 81 CoLUM. L. REv. 1151, 1159-60 (1981); $\mathrm{Li}$, supra note 1 , at 128 . This tax competition has been disfavored in recent years as 
observation by pointing out (1) that because of developing countries' deficits in economic inputs, investments in those countries will usually have lower pretax returns than competing investments in wealthy countries, (2) that worldwide taxation with a limited foreign tax credit and a cross-crediting barrier (i.e., real worldwide taxation) will inevitably cause those lower pretax returns to morph into lower after-tax returns, ${ }^{184}$ and (3) that poor countries, therefore, will be permanently disadvantaged in competing for international investment capital unless they are given relief from the consequences of real worldwide taxation. ${ }^{185}$ Nevertheless, this argument is clearly a plea for economic aid in the form of nonresistance to the impact of low source taxes on the tax bases of residence countries. ${ }^{186}$

We agree with the proposition that comparatively wealthy countries like the United States should assist developing countries out of both a duty to do so and a proper understanding of U.S. selfinterest. ${ }^{187}$ Recognizing a duty to assist is not, however, the same as agreeing that developing countries have the right to define the type, amount, and terms of the assistance. Thus, with respect to the present discussion, no normative principle requires the United States to passively accept appropriation of its tax base by low-tax developing countries without inquiry into whether those countries are hostile or friendly to the United States, oppressive or committed to the rule of law, democratically governed or ruled by kleptocrats, ${ }^{188}$ and a host of

inhibiting the revenue mobilization required to fund critical public goods that are the foundation for successful foreign direct investment and are essential to achieve development goals. See, e.g., OECD, Action Plan, supra note 82, at 10, 13-19; SLEMroD \& GILLITZER, supra note 25, at 180-81; Joel Slemrod \& John D. Wilson, Tax Competition with Parasitic Tax Havens, 93 J. PUB. ECON. 1261 (2009). For a contrary view, see Elkins, supra note 50 (defending tax competition on worldwide efficiency and welfare grounds).

184. This is the case because a real worldwide system's currently imposed residual tax causes investments that have a comparatively higher before-tax rate of return to also have a comparatively higher after-tax rate of return. See Fleming, Peroni \& Shay, Perspectives, supra note 26 , at 1084-85.

185. Professor Rust explained this argument to one of us at a workshop conducted in the Doctor of International Business Taxation Program at the Vienna University of Economics and Business in October 2015. We thank him for his assistance.

186. See Li, supra note 1, at 129 (characterizing development assistance through tax sparing as "a cross-border tax subsidy").

187. See supra text accompanying notes 110-112.

188. See Corruption Perceptions Index 2014, TrANSPARENCY InT'L, www.transparency. org/cpi2014 (last visited Sept. 4, 2016) (showing that the world's developing countries are, with exceptions, plagued by corruption); see also Michael Littlewood, Tax Competition: Harmful to Whom?, 26 MiCH. J. INT'L. L. 411, 441 (2004) ("'II]t seems difficult to categorize the withholding of aid as a violation of sovereignty."). 


\author{
other similar considerations. ${ }^{189}$ A real worldwide system coupled with \\ negotiated, carefully tailored tax sparing $^{190}$ and direct monetary
}

189. See Anthony C. Infanti, Internation Equity and Human Development, in TAX, LAW AND DEVElopMent 209, 238 (Yariv Brauner \& Miranda Stewart eds., 2013) ("A more robust notion of internation equity that aims at advancing human development could be used to sort out 'worthy' from 'unworthy' recipients of development assistance. Those with a record of promoting advances in human development . . . could easily be targeted for greater aid than those without such a record."). But see Luís Eduardo Schoueri, Tax Sparing: A Reconsideration of the Reconsideration, in TAX, LAW AND DEVELOPMENT, supra, at 106, 12023 (apparently arguing that residence countries should not have this level of discretion when the issue is whether residence countries should use tax sparing credits to accommodate tax incentives granted by developing countries).

190. See Fleming, Peroni \& Shay, Fairness in International Taxation, supra note 2, at 344-49; Li, supra note 1 , at 128-29. Tax sparing usually means that the residence country allows a foreign tax credit not only for income taxes actually paid by a resident to a developing country but also for income taxes that would have been paid if the developing country had not applied a temporarily reduced tax to the resident as an inducement for the resident to locate business or investment activity in the developing country. See GUSTAFSON, PERONI \& PUGH, supra note 3, at 404. In principle, however, tax sparing could be applied to the permanent difference between the low income tax rate in a developing country and the higher rate in the residence country.

The OECD has issued a report on tax sparing, which seeks to develop among the OECD countries "a more coherent position towards the granting [and design] of tax sparing [provisions]." ORG. FOR ECON. CO-OPERATION \& DEV., TAX SPARING: A RECONSIDERATION 3 (1998). "[T]his report does not suggest that OECD and other countries which have traditionally granted tax sparing should necessarily cease to do so." Id. at 42 . However, the OECD report did identify "a number of concerns that put into question the usefulness of the granting of tax sparing relief," including (1) the vulnerability of tax sparing to taxpayer abuse; (2) the effectiveness of tax sparing as a method for providing foreign aid and promoting economic development; and (3) "general concerns with the way in which tax sparing may encourage countries to use tax incentives." Id. at 41. But see Schoueri, supra note 189 (criticizing the OECD report).

In this Article, we do not take sides in the debate over whether it is prudent for developing countries to attempt to attract foreign capital with tax incentives. In addition, we note that it is difficult for the United States to use bilaterally negotiated tax sparing credits. This difficulty arises because of most favored nation commitments to extend those credits to several other countries in addition to a treaty partner who obtained the credits through bilateral negotiations. See, e.g., Protocol to the Convention Between the Government of the Republic of Kazakhstan and the Government of the United States of America for the Avoidance of Double Taxation and the Prevention of Fiscal Evasion with Respect to Taxes on Income and Capital, para. 8.d (Oct. 24, 1993). Our point is that if the United States determines that a particular developing country's income tax incentive should be accommodated, then carefully designed tax sparing is the preferable approach in comparison to adoption of a generally applicable territorial system.

Regarding the need to carefully tailor tax sparing treaty provisions to avoid untoward results and how to do so, see Kim Brooks, Tax Sparing: A Needed Incentive for Foreign Investment in Low-Income Countries or an Unnecessary Revenue Sacrifice?, 34 QUEEN's L.J. 505 (2009). For a sampling of the other commentary on tax sparing, see TIMO

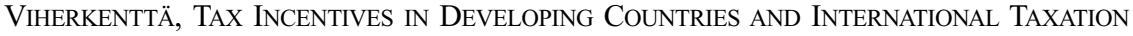
(1991); Mary Bennett, Reflections on Current U.S. Policy for Developing Country Tax Treaties, 2 TAX Notes InT'L 698 (1990); B. Anthony Billings \& Gary A. McGill, Tax Sparing on U.S. Multinationals, 48 TAX NOTES 615 (1990); Kingson, supra note 183, at 1262-72; Richard D. Kuhn, United States Tax Policy with Respect to Less Developed Countries, 32 
transfers allows for these distinctions to be made without the untoward effects of a territorial system. In contrast, a generally applicable territorial system is a blunt instrument that permits all lowtax countries to enjoy the full advantages of their low rates without any of the preceding distinctions being made among those countries, including distinctions between relatively poor countries (Mozambique, to give one example) and relatively wealthy countries that have chosen low tax rates as a competitive measure (e.g., Ireland).

Some commentators have objected that negotiated tax sparing and direct monetary transfers treat assistance to developing countries as demeaning charity rather than as an entitlement. ${ }^{191}$ This seems inevitable and unremarkable. The sovereign right ${ }^{192}$ of a wealthy country to decide how its not unlimited tax base will be used and to make the kinds of distinctions between developing countries that were suggested above means that discretion resides unavoidably in the hands of wealthy countries. The relevant analogy is to the field of charitable donations where donees are spread across a spectrum in terms of their integrity and effectiveness. Consequently, donors are encouraged to investigate these and other characteristics of their potential donees and means are made freely available for them to do so. ${ }^{193}$ Elected officials should do no less in their roles as stewards of their respective countries' tax bases.

The argument that wealthy countries that employ worldwide taxation with a foreign tax credit must modify their systems to accommodate the low rates of low-tax countries is effectively an

Geo. Wash. L. Rev. 261 (1963); Jeffrey Owens \& Torsten Fensby, Is There a Need To Reevaluate Tax Sparing?, 16 TAX Notes INT'L 1447 (1998); Richard C. Pugh, The Deferral Principle and U.S. Investment in Developing Countries, in UnITED STATES TAXATION AND DEVElOPING CounTRIES 267, 270-71 (Robert Hellawell ed., 1980); Schoueri, supra note 189; Damian Laurey, Note, Reexamining U.S. Tax Sparing Policy with Developing Countries: The Merits of Falling in Line with International Norms, 20 VA. TAX REV. 467 (2000).

191. See Benshalom, supra note 1 , at 77-78.

192. The concept of sovereignty continues to be a norm that legitimates the exercise of both residence taxation and source taxation. See id. at 73-75; Christians, supra note 1, at 99, 110-11; Ring, supra note 2, at 183; see also Itai Grinberg \& Joost Pauwelyn, The Emergence of a New International Tax Regime: The OECD's Package on Base Erosion and Profit Shifting (BEPS), AM. SOC'Y INT'L L. (Oct. 28, 2015), https://www.asil.org/insights/ volume/19/issue/24/emergence-new-international-tax-regime-oecd's-package-base-erosionand ("Tax policy is ... perceived as one of the last bastions of Westphalian sovereignty."). Stated differently, in the world of international taxation, sovereignty is a two-way street; in the context of assistance from developed countries to developing countries, this means that both the country that seeks assistance and the country that provides assistance have legitimate claims of sovereignty.

193. See ChARITY NAVIGATOR, www.charitynavigator.org (last visited Sept. 4, 2016); CHARITY WATCH, www.charitywatch.org (last visited Sept. 4, 2016). 
argument that the wealthy countries have two mandatory normative options: (1) give a credit for the full amount of income taxes that would have been imposed by low-tax countries if they had not used low rates to attract foreign investment (limited, however, to the tax ordinarily imposed on domestic income by the credit-granting country) or (2) give a credit limited to taxes actually imposed by lowtax countries but make cash transfers to the low-tax countries that equal the taxes not imposed. In a world in which all countries enjoy sovereignty with respect to their expenditures, option (2) is not sustainable as a mandatory norm. Because the former is the equivalent of the latter, it is likewise unsustainable.

Someday, a world norm may arise that gives poorer countries an entitlement to a portion of the wealthy countries' tax bases. But in the present world of Westphalian tax sovereignty, ${ }^{194}$ rich countries are allowed to unilaterally decide what to do with their tax bases so long as they comply with the normative requirement of recognizing the primacy of source taxes that are actually imposed. ${ }^{195}$ The foreign tax credit with negotiated tax sparing and/or foreign aid transfers is consistent with this present world.

In summary, traditional fairness norms do not provide useful guidance on how to allocate the international income tax base among countries. However, the systems of territoriality and worldwide taxation with a limited foreign tax credit provide base allocation schemes that have been long recognized as legitimate under international law. When comparing these two approaches, bona fide concerns over avoiding locational distortions and defending the residual tax base that is normatively assigned to residence countries indicate that the allocation produced by the foreign tax credit approach is superior to the allocation that results from any form of territoriality.

\section{A PRINCIPLED, Nonmanipulable Definition of RESIDENCE IS ESSENTIAL}

Although the limited foreign tax credit that we have defended in this Article is an important element of a well-designed territorial system, our primary interest in the foreign tax credit arises from the fact that it is absolutely critical to the structure of the real worldwide

194. See supra note 192.

195. See supra note 179. 
approach that we have consistently advocated in earlier work. ${ }^{196}$ However, a real worldwide income tax system with a limited foreign tax credit that is protected against significant cross-crediting will provide a strong incentive for existing U.S. resident corporations to become resident corporations in countries with territorial systems. Thus, the final element in a real worldwide system is a definition of corporate residence that U.S. corporations cannot easily manipulate by expedients such as reincorporating in foreign jurisdictions or being acquired by a foreign corporation. We believe that such a definition, based on shareholder residence, is feasible and appropriate, and we will address this matter in a forthcoming article. ${ }^{197}$

\section{Why ONLY Two CHEERS?}

Federal income taxation is the principal device for allocating the cost of the U.S. national government among the residents of the United States. While it is important that this allocation be made in a way that serves economic efficiency, it is arguably equally important that the allocation be made fairly.

The ability-to-pay concept ${ }^{198}$ is the long-standing bedrock U.S. principle for making a fair allocation of the income tax burden. ${ }^{199}$ This is true even for the corporate income tax because, in our view,

196. See generally Fleming, Peroni \& Shay, Formulary Apportionment, supra note 7, at 18-29 (explaining why worldwide taxation without deferral and cross-crediting is the preferred approach for reforming the U.S. international tax regime); Fleming, Peroni \& Shay, Perspectives, supra note 26 (same).

197. J. Clifton Fleming, Jr., Robert J. Peroni \& Stephen E. Shay, Defending Worldwide Taxation with a Shareholder-Based Definition of Corporate Residence, 2016 BYU L. REV. (forthcoming 2016). For our preliminary work on this topic, see Fleming, Peroni \& Shay, Formulary Apportionment, supra note 7, at 21-25; Shay, Fleming \& Peroni, Designing a $21^{\text {st }}$ Century Corporate Tax, supra note 88, at 717-19.

198. For a detailed discussion of the ability-to-pay concept and the controversies surrounding it, see Fleming, Peroni \& Shay, Fairness in International Taxation, supra note 2, at $301 \mathrm{n} .1$.

199. See, e.g., League of Nations Econ. \& Fin. Comm'n, Report on Double Taxation, in 4 JoInt COMm. On InTERnAl REVENUE TAXATION, LEgISLATIVE History OF United States Tax Conventions 4003, 4022 (1962); Richard A. Musgrave \& Peggy B. Musgrave, Public Finance in Theory And Practice 232-40 (4th ed. 1984); Blueprints for Basic Tax Reform, supra note 27, at 1, 24; Fleming, Peroni \& Shay, Fairness in International Taxation, supra note 2, at 318-21; Robert A. Green, The Future of Source-Based Taxation of the Income of Multinational Enterprises, 79 CORNELL L. REV. 18, 29 (1993); Martin J. McMahon, Jr. \& Alice G. Abreu, Winner-Take-All Markets: Easing the Case for Progressive Taxation, 4 FlA. TAX REV. 1, 66-71 (1998); Robert L. Palmer, Toward Unilateral Coherence in Determining Jurisdiction to Tax Income, 30 HARV. INT'L L.J. 1, 9-10 (1989); Joseph T. Sneed, The Criteria of Federal Income Tax Policy, 17 StAN. L. REv. 567, 576-80 (1965). 


\author{
that levy is best understood as a surrogate tax on shareholder \\ income. ${ }^{200}$
}

200. We note that several benefit-based rationales have been advanced to support the existence of a separate tax on corporate income. See, e.g., GEORGE K. YIN \& DAVID J. Shakow, AM. LAW InST., TAXATION OF PRIVATE BusinesS ENTERPRISES 51-54 (1999) [hereinafter ALI, PRIVATE ENTERPRISES] (acknowledging argument that separate corporate tax is justified as a charge for the benefit of limited shareholder liability but finding the argument unpersuasive); Calvin H. Johnson, Replace the Corporate Tax with a Market Capitalization Tax, 117 TAX NOTES 1082, 1084-85 (2007) (arguing that separate corporate tax for publicly traded corporations is justified as a tax on the liquidity benefit of access to public securities markets); Rebecca S. Rudnick, Who Should Pay the Corporate Tax in a Flat Tax World?, 39 CAse W. Res. L. Rev. 965, 994 (1998-89) (same). But see Michael S. Kirsch, The Congressional Response to Corporate Expatriations: The Tension Between Symbols and Substance in the Taxation of Multinational Corporations, 24 VA. TAX REV. 475 (2005) (expressing doubts that the benefits of incorporating in the United States justify the worldwide taxation of corporate income). We further note that some commentators have rationalized the separate corporate income tax as a device for regulating corporate behavior and as a charge for the burdens placed on society by corporate activities. See Reuven S. AviYonah, Corporations, Society, and the State: A Defense of the Corporate Tax, 90 VA. L. REV. 1193, 1254 (2004); Reuven S. Avi-Yonah, Letter to the Editor, Tax Reform in the (Multi)National Interest, 124 TAX NOTES 389 (2009). Other commentators have rationalized the corporate tax as a tax on economic rents earned by firms operating in corporate form. See Mark P. Keightley \& Molly F. Sherlock, Cong. Research Serv., R42726, The CORPORATE INCOME TAX SYSTEM: OVERVIEW AND OPTIONS FOR REFORM 15 (2012).

In our judgment, however, none of these benefits-based rationales justifies a tax on corporate net income as great as the present $35 \%$ top I.R.C. $\S 11$ rate or even the $25 \%$ or $28 \%$ top rate proposed by some reformers. See, e.g., KeIGHTLEY \& SHERLOCK, supra, at 15 ("[T] he corporate tax as currently applied is not a tax on pure profits or economic rents."); ALI, PRIVATE ENTERPRISES, supra, at 60 ("[T] here is no indication that the amount of the tax properly reflects the value of the benefit."); Harry Grubert \& Rosanne Altshuler, Fixing the System: An Analysis of Alternative Proposals for the Reform of International Tax, 66 NAT'L TAX J. 671, 707 (2013) ("The corporate tax is not generally characterized as a benefit tax."); Omri Marian, Jurisdiction to Tax Corporations, 54 B.C. L. REv. 1613, 1659 (2013) ("[I]t probably makes little sense to argue that the current purpose of corporate taxes in the United States is to tax the benefits of incorporation.").

Instead, it is our view that the only persuasive justification for a separate corporation net income tax with a top rate of $35 \%$, or even $25 \%$, is that the tax serves as a crude surrogate levy on shareholders that limits the advantage of differences between the $\S 1$ individual rates and the $\$ 11$ rates. See Jane G. Gravelle \& Thomas L. Hungerford, Cong. Research SERV., RL34229, CORPORATE TAX REFORM: ISSUES FOR CONGRESS 4-5 (2012). Perhaps of greater importance, the corporate tax prevents corporations from being used as tax deferral devices that create time value of money benefits for taxpayers who can earn income through those corporations, instead of directly (i.e., stock investors vs. wage earners). See KEIGHTLEY \& SHERlOcK, supra, at 15; J.D.R. AdAMS \& J. Whalley, THE INTERNATIONAL TAXATION OF Multinational EnTERPRises in DeVEloped COUNTRIES 8-9 (1977); AlVIN C. WARREN JR., AM. LAW INST., INTEGRATION OF THE INDIVIDUAL AND CORPORATE INCOME TAXES 94 (1993); Reuven S. Avi-Yonah \& Amir C. Chenchinski, The Case for Dividend Deduction, 65 TAX LAw. 3, 7 (2011); Kleinbard, Lessons, supra note 53, at 138-39, 159-60. Stated differently, the corporate net income tax should be viewed as a backstop to the individual income tax. See also David A. Weisbach, The Irreducible Complexity of Firm-Level Income Taxes: Theory and Doctrine in the Corporate Tax, 60 TAX L. REV. 215, 217 (2007) ("Firm-level taxes, whether collected at the firm level or calculated at the firm level and passed through to owners, can be seen as a necessary back-up to individual-level income taxes that rely on 
If fairness concerns were the only consideration, we would advocate that the United States treat tax payments by U.S. residents to foreign countries like any other business expense-as an allowable deduction in calculating net income. ${ }^{201}$ The ability-to-pay principle would be satisfied by allowing a deduction for foreign taxes because the deduction would accurately measure the taxpayer's available resources for paying U.S. income tax. Thus, a dollar-for-dollar credit is overly generous from an ability-to-pay standpoint. Moreover, since the bulk of U.S. foreign tax credits are taken by large U.S. multinational corporations, the ultimate beneficiaries of this excessive generosity are the owners of capital, who are concentrated at the highest income levels. ${ }^{202}$ This largess is problematic from a distributional standpoint.

We have seen in subpart III.A, however, that if the United States responded to international double taxation with a foreign tax deduction instead of a foreign tax credit, the result would be a chilling effect on international trade and investment, leading to a serious decline in economic efficiency and the economic welfare of the country. Accordingly, the United States essentially has been faced with a choice between (1) designing an international tax system that is totally faithful to fairness/ability-to-pay concerns (i.e., that treats foreign tax payments as income tax deductions) but that leaves international double taxation substantially in place as a barrier to its residents' foreign business and investment activities or (2) finding a way to ameliorate the double-tax barrier while preserving the abilityto-pay tax base to the greatest extent possible.

The first alternative has been judged unacceptable, and it is difficult to quarrel with this outcome. The United States has elected the second alternative and employs the foreign tax credit to accomplish that end. This is simply a situation in which policymakers have required an important value-fairness, as expressed in the ability-to-pay principle - to give ground to another important, but

realization.”). Because the $\S 11$ tax on corporations is best explained as a substitute for a current shareholder tax, the base of the $\S 11$ tax should be consistent with the same ability-topay principle that applies at the shareholder level-i.e., it should include all of the taxpayer's foreign-source income. Real worldwide taxation achieves this end. Territorial taxation fails to do so.

201. For a discussion of why a deduction for foreign income taxes is sufficient to achieve fairness objectives, see Nancy H. Kaufman, Fairness and the Taxation of International Income, 29 L. \& POL'Y INT'L Bus. 145, 177-78 (1998).

202. See Edward N. Wolff, Household Wealth Trends in the United States, 1962-2013: What Happened Over the Great Recession? 11 (Nat'l Bureau of Econ. Research, Working Paper No. 20733, 2014). 
conflicting, value - ameliorating international double taxation. The compromise is a reasonable one $\mathrm{e}^{203}$ and in no way invalidates the proposition that an income tax system that gives great weight to the ability-to-pay principle should generally include foreign-source income in the tax base. ${ }^{204}$

Moreover, if the foreign country's income tax rate is below the U.S. rate, the United States has the possibility of collecting a residual tax on foreign-source income. Stated differently, where the foreign tax rate is less than the U.S. rate, a foreign tax credit system potentially includes foreign-source income in the U.S. tax base and, to that extent, gives effect to the ability-to-pay principle. By contrast, an exemption system would leave foreign-source income out of the U.S. tax base in all cases, regardless of the relationship of the foreign tax rate to the U.S. rate. This would amount to a blanket renunciation of the ability-to-pay principle instead of a compromise between abilityto-pay and mitigation of international double taxation. In other words, a foreign tax credit system (without deferral and significant crosscrediting) achieves a compromise between the ability-to-pay principle and elimination of double taxation and does so without the distortions of economic behavior resulting from an exemption system.

Notwithstanding the preceding justification, the U.S. foreign tax credit mechanism indisputably compromises the important value of ability-to-pay. For that reason, it merits only two cheers.

\section{VIII.CONCLUSION}

The foreign tax credit is a critical component of the highly defective current U.S. worldwide international income tax system as well as of a more coherent "real" worldwide system, without deferral and significant cross-crediting, which we hope the United States will adopt. This foreign tax credit regime has been subjected to various criticisms which, if valid, may cast doubt on its efficacy as a doubletax mitigation device and may strengthen the case for moving to a territorial system. Thus, the soundness of the foreign tax credit is an important element in the worldwide versus territorial taxation debate.

Moreover, real-world territorial systems often apply worldwide taxation treatment with a foreign tax credit to passive income, to income that bears a very low foreign tax, and to income of

203. For a detailed explanation of this point, see Fleming, Peroni \& Shay, Fairness in International Taxation, supra note 2, at 328-33.

204. See generally id. at 311-13 (demonstrating how the source of income is immaterial to ability-to-pay). 
noncorporate taxpayers. Thus, the efficacy of the foreign tax credit approach to ameliorating international double taxation is an issue that is also relevant to territorial systems.

The U.S. foreign tax credit has been criticized for being inconsistent with the economic standard of capital export neutrality, for stimulating other countries to increase their source taxation of U.S. residents, for undermining the efforts of developing countries to attract foreign investment with tax incentives, and for failing to incentivize U.S. residents to minimize their foreign tax liabilities and thus increase their liabilities for U.S. residual tax. This last criticism has resulted in a proposal to replace the U.S. foreign tax credit with a deduction for foreign income tax liabilities coupled with a lower U.S. tax on foreign income.

We have explained why full consistency with the standard of capital export neutrality is not an important criterion for evaluating the foreign tax credit. We have also explained why the U.S. foreign tax credit is unlikely to have a meaningful restraining effect on foreign tax minimization planning by U.S. residents or to cause problematic behavior by foreign countries. In addition we have explained why a foreign tax deduction coupled with a lower rate of tax on foreign income would produce erratic results that would be inferior to outcomes under a foreign tax credit regime.

We have also examined the role of the foreign tax credit in allocating the international income tax base between residence countries and source countries and concluded that the foreign tax credit effectively imposes a "use it or lose it" rule that protects the United States against efforts to erode the U.S. tax base by using low tax rates to lure U.S. residents' business and investment activity away from the United States. We have concluded that this "use it or lose it" rule has an overall salutary effect and that untoward impacts on developing countries should be addressed with bilaterally negotiated tax sparing and direct monetary assistance.

Notwithstanding its virtues, however, the foreign tax credit unavoidably conflicts with the principle of ability-to-pay. Although we find this conflict to be an acceptable cost to bear in exchange for resulting benefits, the conflict limits us to only two cheers for the foreign tax credit. 